\title{
Graphene Oxide-based Nanomaterials for Uranium Adsorptive Uptake
}

\author{
Hongjuan $\mathrm{Liu}^{1,2}$ and Yuanbing Mao,
}

\begin{abstract}
The growth of nuclear power generation and the necessity to acquire uranium reserves for energy security and pollution regulation for environmental protection put much emphasis on the removal and recovery of uranium from aqueous solutions. Adsorption has been proved to be a promising method for this purpose method because of its high adsorption efficiency, easy operation, low cost, reusability and availability of massive adsorbents. Among a wide variety of adsorbents, graphene oxide (GO) has demonstrated excellent adsorption potential for uranium uptake and recovery due to its unique 2D structure, high specific surface area and abundant oxygen-containing functional groups. Regarding the functional groups, it can make GO with high dispersion and hydrophilicity and participate in the complexation of uranium, leading to high adsorption efficiency for uranium. In this review, the research status and progress of GO-based nanomaterials for uranium adsorption are summarized. Their adsorption capacities, influencing factors, kinetics, isotherms and thermodynamics are compared and discussed. The microscopic mechanisms of uranium adsorption onto these GO-based nanomaterials are elaborated at molecular level by spectral analysis, surface complexation models, and theoretical calculations. Meanwhile, the challenges and research trends in the study of uranium adsorption by GO-based nanomaterials are pointed out. We believe that our focused review provides not only a summarizing reference on the current status of uranium removal and recovery by GObased nanomaterials, but also future directions for related follow-up research and practical applications.
\end{abstract}

Keywords: Uranium; Nanomaterials; Graphene oxide; Adsorption; Removal and recovery.

Received date: 19 February 2021; Accepted date: 15 April 2021.

Article type: Review article.

\section{Introduction}

The world's energy demand is increasing continually with the rapid development of economy and the fast-growing population. The extensive use of fossil energy has recently caused serious environmental issues, and traditional fossil fuels are also facing the shortage problems. ${ }^{[1-3]}$ The global energy shortage and environmental problems have promoted the development of efficient and clean energy. ${ }^{[4-6]}$ Nuclear power plays a significant role in addressing the energy shortage ${ }^{[7-10]}$ and mitigating environmental problems such as the climate change. ${ }^{[11,12]}$ Uranium, as a critical radioactive element, has been widely used to produce nuclear power, which is increasing the necessity for uranium as an energy resource. ${ }^{[13-16]}$ However, uranium and its radioactive isotopes contribute to a high-level of nuclear waste, which needs to be

\footnotetext{
${ }^{1}$ Department of Chemistry, Illinois Institute of Technology, 3101 South Dearborn Street, Chicago, IL 60616, USA.

${ }^{2}$ School of Nuclear Science and Technology, University of South China, Hengyang, 421001, China.

*Email: ymao17@iit.edu (Y. Mao)
}

properly disposed. Therefore, we carried out speciation (e.g. oxidation state and coordination geometry) study of uranium ion doped in $\mathrm{RE}_{2} \mathrm{Hf}_{2} \mathrm{O}_{7}$ serves as a prerequisite for their capability for nuclear waste immobilization and eventually safe nuclear energy and sustainable environment. ${ }^{[15,16]}$ Moreover, the terrestrial deposits of uranium are predicted to become a shortage owning to the booming energy demand. Seawater also contains uranium at low concentrations $(\sim 3.3$

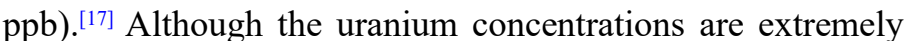
low, seawater represents an inexhaustible source of uranium which is estimated at approximately 4.5 billion tons - nearly 1,000 times of the entire available terrestrial deposits of uranium. Development of highly efficient and selective adsorbents capable of recovering uranium from seawater would be valuable to ensuring the availability of uranium resources.

On the other hand, the vigorous exploitation of nuclear power has also posed potential harms to ecological environment and human health. Due to uranium mining and processing activities, nuclear accidents and improper nuclear waste treatment, a large amounts of uranium species have 
Table 1. Adsorption capacities and main parameters of uranium adsorption by GO-based nanomaterials

\begin{tabular}{|c|c|c|c|c|c|c|}
\hline Adsorbents & $\mathrm{pH}$ & $\begin{array}{c}\text { Ambient } \\
\text { temperature } \\
(\mathrm{K})\end{array}$ & $\begin{array}{l}\text { Adsorption } \\
\text { capacity } \\
\left(\mathrm{mg} \mathrm{g}^{-1}\right) \\
\end{array}$ & $\begin{array}{c}\text { Isotherm } \\
\text { model }\end{array}$ & Thermodynamics & Ref. \\
\hline GO & 3.45 & 298 & 94.25 & $\begin{array}{l}\text { Langmuir } \\
\text { Isotherm }\end{array}$ & endothermic/spontaneous & [76] \\
\hline GO & 6.8 & 293 & 99 & $\begin{array}{l}\text { Langmuir } \\
\text { Isotherm }\end{array}$ & endothermic & {$[77]$} \\
\hline GO & 4.4 & 298 & 330.82 & $\begin{array}{l}\text { Langmuir } \\
\text { Isotherm }\end{array}$ & endothermic /spontaneous & [78] \\
\hline GO & 6.0 & 298.15 & 309.09 & $\begin{array}{l}\text { Langmuir } \\
\text { Isotherm }\end{array}$ & endothermic/spontaneous & [79] \\
\hline GO & 5.0 & 293 & 97.5 & n.a. & endothermic /spontaneous & [80] \\
\hline GO & 4.0 & 303 & 208.33 & $\begin{array}{l}\text { Langmuir } \\
\text { Isotherm }\end{array}$ & endothermic/spontaneous & [81] \\
\hline GO & 4.0 & RT & 299 & $\begin{array}{l}\text { Langmuir } \\
\text { Isotherm }\end{array}$ & endothermic/spontaneous & [82] \\
\hline rGO & 4.0 & RT & 47 & n.a. & n.a. & {$[82]$} \\
\hline $\mathrm{CGO}$ & 4.5 & 298 & 240.1 & $\begin{array}{l}\text { Langmuir } \\
\text { Isotherm }\end{array}$ & n.a. & {$[70]$} \\
\hline EGO & 4.5 & 298 & 75.2 & $\begin{array}{l}\text { Langmuir } \\
\text { Isotherm }\end{array}$ & n.a. & {$[70]$} \\
\hline $\mathrm{BGO}$ & 4.5 & 298 & 68.8 & $\begin{array}{l}\text { Langmuir } \\
\text { Isotherm }\end{array}$ & n.a. & {$[70]$} \\
\hline OGO & 5.5 & 303 & 291.8 & n.a. & endothermic/spontaneous & {$[71]$} \\
\hline GOC & 5.0 & 303 & 101.0 & $\begin{array}{l}\text { Freundlich } \\
\text { Isotherm }\end{array}$ & n.a. & {$[46]$} \\
\hline $\mathrm{GO}-\mathrm{NH}_{2}$ & 5.5 & 298.15 & 215.2 & $\begin{array}{l}\text { Langmuir } \\
\text { Isotherm }\end{array}$ & endothermic /spontaneous & {$[83]$} \\
\hline GONRs & 4.5 & 298 & 394.1 & $\begin{array}{l}\text { Langmuir } \\
\text { Isotherm }\end{array}$ & endothermic/spontaneous & {$[84]$} \\
\hline GONRs/CTS & 5 & 298 & 320 & $\begin{array}{c}\text { Freundlich } \\
\text { Isotherm }\end{array}$ & endothermic /spontaneous & {$[47]$} \\
\hline GO-CNTs & 5.0 & 298.15 & 86.1 & $\begin{array}{l}\text { Langmuir } \\
\text { Isotherm }\end{array}$ & endothermic/spontaneous & {$[85]$} \\
\hline GO-ACF & 5.5 & 298 & 298 & $\begin{array}{l}\text { Langmuir } \\
\text { Isotherm }\end{array}$ & endothermic/spontaneous & {$[86]$} \\
\hline MIL-68/GO & 8.0 & 298 & 594.66 & $\begin{array}{l}\text { Langmuir } \\
\text { Isotherm }\end{array}$ & endothermic & {$[87]$} \\
\hline rGO/ZIF-67 & 4.01 & 298 & 1888.55 & $\begin{array}{l}\text { Langmuir } \\
\text { Isotherm }\end{array}$ & endothermic/spontaneous & {$[10]$} \\
\hline GZA & 7.0 & 298 & 602.41 & $\begin{array}{c}\text { Freundlich/ } \\
\text { Langmuir }\end{array}$ & endothermic/spontaneous & {$[88]$} \\
\hline GCZ8A & 8.0 & 298.15 & 361.01 & $\begin{array}{l}\text { Freundlich } \\
\text { Isotherm }\end{array}$ & n.a. & {$[43]$} \\
\hline $\mathrm{CMC} / \mathrm{MGOs}$ & 5.5 & 301 & 188.97 & $\begin{array}{l}\text { Langmuir } \\
\text { Isotherm }\end{array}$ & endothermic & [89] \\
\hline AOMGO & 5.0 & 298 & 284.9 & $\begin{array}{l}\text { Langmuir } \\
\text { Isotherm }\end{array}$ & endothermic /spontaneous & {$[90]$} \\
\hline $\mathrm{PAO} / \mathrm{rGO}$ & 4.0 & 293 & 872 & $\begin{array}{l}\text { Langmuir } \\
\text { Isotherm }\end{array}$ & endothermic /spontaneous & [91] \\
\hline
\end{tabular}




\begin{tabular}{|c|c|c|c|c|c|c|}
\hline Adsorbents & $\mathrm{pH}$ & $\begin{array}{c}\text { Ambient } \\
\text { temperature } \\
(\mathrm{K})\end{array}$ & $\begin{array}{c}\text { Adsorption } \\
\text { capacity } \\
\left(\mathrm{mg} \mathrm{g}^{-1}\right) \\
\end{array}$ & $\begin{array}{l}\text { Isotherm } \\
\text { model }\end{array}$ & Thermodynamics & Ref. \\
\hline PA-GO & 5.5 & 298 & 124.3 & $\begin{array}{l}\text { Langmuir } \\
\text { Isotherm }\end{array}$ & n.a. & {$[92]$} \\
\hline $\begin{array}{c}\mathrm{HO}- \\
\mathrm{CB}[6] / \mathrm{GO}\end{array}$ & 5.0 & 298 & 301.6 & $\begin{array}{l}\text { Langmuir } \\
\text { Isotherm }\end{array}$ & endothermic/spontaneous & [93] \\
\hline $\mathrm{CD} / \mathrm{GO}$ & 5.0 & 288 & 97.3 & $\begin{array}{l}\text { Langmuir } \\
\text { Isotherm }\end{array}$ & n.a. & [93] \\
\hline PANI/GO & 5.0 & 293 & 1960 & n.a. & n.a. & [94] \\
\hline $\mathrm{PAM} / \mathrm{GO}$ & 5.0 & 295 & 166.12 & $\begin{array}{l}\text { Langmuir } \\
\text { Isotherm }\end{array}$ & endothermic/spontaneous & [95] \\
\hline GO-PDA & 5.5 & 298 & 718 & $\begin{array}{l}\text { Langmuir } \\
\text { Isotherm }\end{array}$ & endothermic/spontaneous & {$[96]$} \\
\hline $\begin{array}{c}\mathrm{GO} / \mathrm{PDA} / \mathrm{PA} \\
\mathrm{O}-0.2\end{array}$ & 6 & 298 & 502.5 & $\begin{array}{l}\text { Langmuir } \\
\text { Isotherm }\end{array}$ & endothermic/spontaneous & {$[73]$} \\
\hline GO-pDA-PEI & 5.0 & 298 & 530.6 & $\begin{array}{l}\text { Langmuir } \\
\text { Isotherm }\end{array}$ & $\begin{array}{l}\text { exothermic } \\
\text { /spontaneous }\end{array}$ & {$[97]$} \\
\hline $\begin{array}{c}\text { PEI- } \\
\mathrm{rGO} / \mathrm{MoS}_{2} \\
\mathrm{CAs}-3\end{array}$ & 8.0 & 298 & 572.05 & $\begin{array}{l}\text { Langmuir } \\
\text { Isotherm }\end{array}$ & endothermic/spontaneous & [98] \\
\hline $\mathrm{PEI} / \mathrm{GO}$ & 7 & 303 & 145.14 & $\begin{array}{l}\text { Langmuir } \\
\text { Isotherm }\end{array}$ & n.a. & [49] \\
\hline MBTA-GO & 3.5 & 298 & 264 & $\begin{array}{l}\text { Langmuir } \\
\text { Isotherm }\end{array}$ & n.a. & [99] \\
\hline $\begin{array}{c}\text { GO/PEDOT:P } \\
\text { SS }\end{array}$ & 4.5 & 298 & 384.51 & Langmuir Isotherm & endothermic & {$[100]$} \\
\hline GO-DM-AO & 8.02 & 298 & 935 & Langmuir Isotherm & endothermic/spontaneous & {$[75]$} \\
\hline GO-CS-AO & 6.0 & 308 & 248.75 & $\begin{array}{l}\text { Langmuir } \\
\text { Isotherm }\end{array}$ & endothermic & {$[101]$} \\
\hline GO-CMC-AO & 6.0 & 308 & 327.86 & $\begin{array}{l}\text { Langmuir } \\
\text { Isotherm }\end{array}$ & endothermic & {$[101]$} \\
\hline MCGO & 5.0 & 313 & 204.1 & $\begin{array}{l}\text { Langmuir } \\
\text { Isotherm }\end{array}$ & endothermic/spontaneous & {$[102]$} \\
\hline $\mathrm{FH} / \mathrm{GOA}$ & 5.0 & 293 & 288.64 & $\begin{array}{c}\text { Langmuir } \\
\text { Isotherm }\end{array}$ & endothermic/spontaneous & {$[45]$} \\
\hline $\begin{array}{l}\text { Lysinibacillus } \\
\text {-GO }\end{array}$ & 4.5 & 303 & 149.3 & Langmuir Isotherm & n.a. & [103] \\
\hline GO-TW & 5 & 298 & 111.61 & $\begin{array}{l}\text { Langmuir } \\
\text { Isotherm }\end{array}$ & endothermic/spontaneous & [104] \\
\hline $\begin{array}{c}\mathrm{rGO} / \mathrm{Fe}_{3} \mathrm{O}_{4} / \mathrm{T} \\
\mathrm{W}\end{array}$ & 5 & 298 & 103.84 & $\begin{array}{l}\text { Langmuir } \\
\text { Isotherm }\end{array}$ & endothermic/spontaneous & [104] \\
\hline $\mathrm{Fe}_{3} \mathrm{O}_{4} / \mathrm{GO}$ & 5.0 & 298 & 28.32 & $\begin{array}{l}\text { Langmuir } \\
\text { Isotherm }\end{array}$ & endothermic/spontaneous & {$[105]$} \\
\hline $\mathrm{Fe}_{3} \mathrm{O}_{4} / \mathrm{GO}$ & 5.5 & 293 & 69.49 & n.a. & endothermic & [106] \\
\hline $\begin{array}{c}\mathrm{CB}[6] / \mathrm{GO} / \mathrm{Fe} \\
{ }_{3} \mathrm{O}_{4}\end{array}$ & 5.0 & 298 & 66.8 & n.a. & n.a. & [107] \\
\hline $\begin{array}{c}\mathrm{MnO}_{2}-\mathrm{Fe}_{3} \mathrm{O}_{4}- \\
\mathrm{rGO}\end{array}$ & 6.0 & 328 & 108.7 & $\begin{array}{l}\text { Langmuir } \\
\text { Isotherm }\end{array}$ & endothermic/spontaneous & [108] \\
\hline
\end{tabular}




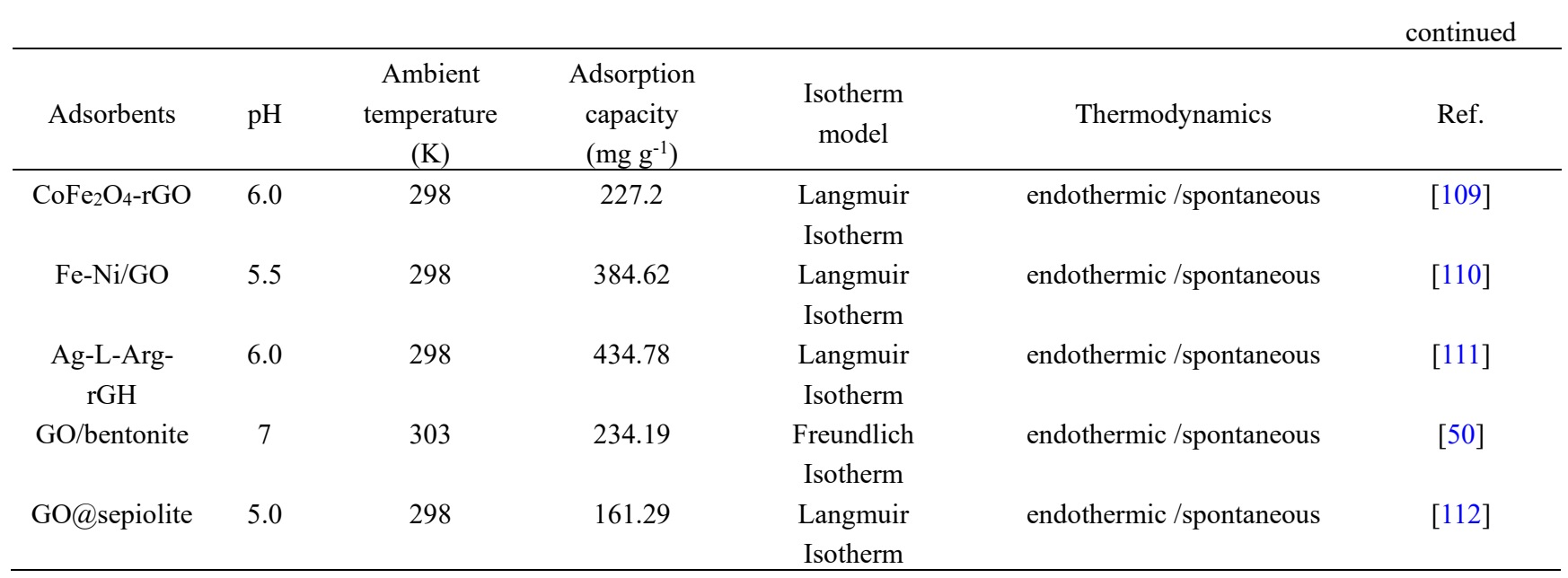

*RT: Room Temperature. n.a.: not application.

released into the water system. Uranium in aqueous solutions mainly exists as soluble uranyl ions which are highly toxic and easily migrate. ${ }^{[18-20]}$ The exposure to excessive uranium can result in DNA damage and dangerous health issues such as liver disease and lung cancer. ${ }^{[21-23]}$ Thus, it is greatly important to remove and recycle uranium from aqueous solutions for environmental conservation, human health, and sustainable development of nuclear energy. ${ }^{[24,25]}$

In the last few decades, various treatment techniques including biological treatments, ${ }^{[26]}$ membrane treatment, ${ }^{[27,28]}$ adsorption, ${ }^{[29-32]}$ advance oxidation processes, ${ }^{[33]}$ chemical precipitation processes, ${ }^{[34]}$ ion exchange, ${ }^{[35-37]}$ and electrochemical method ${ }^{[38-40]}$ have been developed to uptake uranium from aqueous solutions. However, most of these methods have various drawbacks. For example, although chemical precipitation is comparably simple and costeffective, they have difficulty reducing metal ion concentrations below legally limited levels and often produce large amounts of sludge. Among these methods, adsorption is a promising and effective method because of its high adsorption efficiency, easy operation, low cost, reusability and availability of massive adsorbents. ${ }^{[41,42]}$ Recent advances of nanomaterials have provided ample opportunities to develop and employ more efficient radioactive wastewater treatment technologies. Graphene oxide (GO)-based nanomaterials have attracted significant interests because of their unique physicochemical properties such as high specific surface area, high chemical stability and abundant oxygen-containing functional groups. ${ }^{[43,44]}$ These properties make GO-based nanomaterials to be promising candidates for adsorption uranium. For example, Li et al. assembled fungal hypha/GO aerogel as high-performance adsorbents for $\mathrm{U}(\mathrm{VI})$ removal. ${ }^{[45]}$ This fungal hypha/GO aerogel exhibited an excellent capability on U(VI) removal due to its large specific surface area $\left(894 \mathrm{~m}^{2} / \mathrm{g}\right)$ and abundant functional groups. Yang et al. found that GO-cellulose (GOC) composites were promising absorbents for uranium wastewater treatment. ${ }^{[46]} \mathrm{Hu}$ et al. also found that the GO nanoribbons/chitosan (GONRs/CTS) composite membrane was suitable for separating and recovering uranium from wastewater. ${ }^{[4]}$

To date, the adsorption of uranium by GO-based nanomaterials has been extensively studied. ${ }^{[48]}$ This relevant research work has also been carried out in our laboratory. ${ }^{[49-51]}$ However, there have been few reviews that have specially focused on GO-based nanomaterials for uranium adsorption. ${ }^{[52-67]}$ Thereby, a needful review on the recent progress of GO-based nanomaterials for uranium adsorption is expected to promote the development of GO-based nanomaterials in the removal and recovery applications of uranium from aqueous solution. In this review, the adsorption capacities of GO-based nanomaterials are introduced. The influencing factors, kinetics, isotherms and thermodynamics of GO-based nanomaterials for uranium adsorption are analyzed. Moreover, the interaction mechanisms between uranium ions and the GO-based nanomaterials are expounded. Meanwhile, the challenges and research trends in studying the uranium adsorption by GO-based nanomaterials are pointed out. We believe that this focused review for the emerging research on uranium adsorption by GO-based nanomaterials is important for the future uranium removal and recovery technology development. This will also provide an important reference for relevant follow-up research and practical applications.

\section{Adsorption capacities of GO-based nanomaterials}

GO has a wide variety of functional groups on their surface and edges, such as hydroxyl group, epoxy group, carboxyl, carbonyl, etc. ${ }^{[1,47]}$ Due to these oxygen-containing functional groups, GO possesses features such as high dispersion, hydrophilicity, and compatibility, making it a suitable support material to combine with other chemical functional groups or composites as demonstrated in our previous studies among many others. ${ }^{[68,69]}$ Meanwhile, the functional groups of GO can provide active adsorption sites for environmental pollutants, such as uranium and other radioactive species in wastewater. For the past few years, a large number of studies on GO-based nanomaterials as adsorbents of uranium have been carried out. The GO-based nanomaterials for uranium adsorption along 
their capacities are summarized in Table 1 .

The adsorption capacities of the GO-based nanomaterials for uranium strongly depend on the functional groups on GO and experimental conditions. According to the results in Table 1 , pristine GOs have different adsorption capacities due to its distinct synthesis procedures and factors affecting adsorption. Regarding synthesis procedures, different oxidation processes of the Hummers method (the major method to synthesize GO) can affect the type and distribution of functional group on GO, leading to different uranium adsorption capacities. The uranium adsorption capacity of GO is commonly higher than reduced $\mathrm{GO}(\mathrm{rGO})$, which is because there are much more functional groups on GO than $\mathrm{rGO}$. CGO, EGO, and BGO were synthesized from chemical oxidation, electrolysis, and ball-milling of graphene sheets by the modified Hummers method. The adsorption capacity of the CGO $(240.1 \mathrm{mg} / \mathrm{g})$ was three times higher than those of the EGO $(75.2 \mathrm{mg} / \mathrm{g})$ and the BGO $(68.8 \mathrm{mg} / \mathrm{g})$. The CGO with high performance was due to that the amount and type of oxygen functional groups on it was much more abundant than those of the EGO and BGO, which was proved by SEM, FT-IR, Raman, XRD and XPS measurements. ${ }^{[70]} \mathrm{OGO}$ was generated from GO oxidized by ozone. The oxidization of ozone made the OGO with high adsorption performance due to higher oxygen-containing functional groups. ${ }^{[71]}$ These results indicated that the functional groups on GO played an important role in the removal and recovery of uranium. ${ }^{[72]}$ In addition, the adsorption capacities of modified GOs can generally be enhanced by various modification methods, which could be due to improve the dispersion and stability as well as the introduction of more surface-active sites and functional groups. For example, through the assembly of zeolitic imidazolate framework-67 (ZIF-67) on rGO hydrogel, the rGO/ZIF-67 aerogel exhibited an excellent uranium adsorption capacity of $1888.55 \mathrm{mg} / \mathrm{g}$, which was much higher than that of the initial rGO $\quad(134.23 \mathrm{mg} / \mathrm{g}) .^{[10]}$ The adsorption capacity of GO/PDA/PAO-0.2 was $502.5 \mathrm{mg} / \mathrm{g}$, which was higher than that of the initial GO $(342.5 \mathrm{mg} / \mathrm{g})$. The XPS results revealed that $\mathrm{U}(\mathrm{VI})$ coordinated with amidoxime and imine/amine groups, indicating that the $\mathrm{U}(\mathrm{VI})$ was adsorbed on PAO and PDA groups. ${ }^{[73]}$ Graphene oxide /hydroxyapatite (GO/HAP) was synthesized by directly assembling GO and HAP through a facile hydrothermal method. The GO/HAP composite had an outstanding adsorption capacity for U(VI) $(373 \mathrm{mg} / \mathrm{g})$ which was higher than that of GO $(85 \mathrm{mg} / \mathrm{g})$. XRD, FT-IR and XPS results indicated that the phosphate group from HAP was responsible for $\mathrm{U}(\mathrm{VI})$ retention and incorporation. The GO/HAP composite's enhanced U(VI) adsorption capacity was most likely due to the synergistic effect after functionalizing with nanostructured HAP. ${ }^{[74]}$ Similarly, through post-decoration with amidoxime functionalized diaminomaleonitrile (DM-AO) onto GO, the U(VI) adsorption capacity of the GO-DM-AO reached $935 \mathrm{mg} / \mathrm{g}$, which was increased by $209 \%$ compared with that of the pristine GO. The increased adsorption capability of the GO-DM-AO was due to the introduction of organic groups on the GO to increase the number of binding spots and the activation of the inactive points on the GO by cycloaddition reaction. ${ }^{[75]}$

In conclusion, the adsorption capacities of the GO-based nanomaterials for uranium strongly depend on the functional groups on GO and experimental conditions. Pristine GOs have different adsorption capacities affected by their distinct synthesis procedures. The adsorption capacities of modified GOs are generally enhanced by their specific modification methods.

3. Affecting factors, kinetics, isotherm and thermodynamic Generally, the performance of GO-based nanomaterials for uranium adsorption are affected by many factors, such as the solution $\mathrm{pH}$ value, temperature, contact time, ionic strength, co-existing ions, etc. The batch experiments of the effect of affecting factors on the uranium adsorption has been extensively carried out for the application to the treatment of uranium pollution. To some extent, the interaction mechanism can also be expounded based on the results of the effect of affecting factors. ${ }^{\left[{ }^{[7]}\right]}$ For example, the kinetic parameters from time-dependent adsorption experiments, the isotherms and thermodynamic parameters from the fittings of the temperature-dependent adsorption experiments can provide further information about the interactions between the adsorbents and adsorbates. The effect of adsorption affecting factors on GO-based nanomaterials for uranium is discussed below:

\subsection{Effect of solution pH value}

Solution $\mathrm{pH}$ value is one of the most important factors affecting uranium adsorption by GO-based materials. The $\mathrm{pH}$ value of uranium-containing solutions can affect uranium species in the solution and the surface charge of GO-based nanomaterials, thus affecting the interaction between such GO-based nanomaterials and uranium species, which leads to different adsorption efficiencies at various $\mathrm{pH}$ values. For example, Zhao et al. ${ }^{[0]}$ found that the adsorption efficiency of $\mathrm{U}(\mathrm{VI})$ by amineoxime magnetic GO composites (AOMGO) gradually increased from about $50 \%$ to $99 \%$ with increasing the $\mathrm{pH}$ value from 3 to 7 , and began to decline when the $\mathrm{pH}$ value was higher than 8 . Tan et al ${ }^{[108]}$ studied the influence of $\mathrm{pH}$ value on the adsorption of uranium by $\mathrm{MnO}_{2}-\mathrm{Fe}_{3} \mathrm{O}_{4}-\mathrm{rGO}$. The adsorption amount of uranium by the $\mathrm{MnO}_{2}-\mathrm{Fe}_{3} \mathrm{O}_{4}-\mathrm{rGO}$ first increased and then decreased within the range of $\mathrm{pH}$ value of 2-12. Dai et al. ${ }^{[73]}$ found the adsorption capacity of $\mathrm{GO} / \mathrm{PDA} / \mathrm{PAO}$ increased rapidly at $\mathrm{pH}$ from 3 to 6 and then decreased with the increase of $\mathrm{pH}$ value from 6 to 8 due to the change of the species distribution of $\mathrm{U}(\mathrm{VI})$ and the surface of GO/PDA/PAO with increasing $\mathrm{pH}$ value (Fig. 1a, 1c, 1d). Similarly, Zhu et al. studied the effect of solution $\mathrm{pH}$ value for the adsorption of uranium by Ag-L-Arg-rGH composites in the range of $2-9 .{ }^{[111]}$ The results showed that the adsorption capacity was increased at $\mathrm{pH}$ range from 2 to 6 and the highest adsorption capacity was obtained at $\mathrm{pH}=6$, and then the 
uranium (VI) removal capability reduced with the $\mathrm{pH}$ value higher than 6. Other relevant literature also found that the adsorption of GO-based nanomaterials for uranium was strongly dependent on solution $\mathrm{pH}$ value. ${ }^{[82,83]}$

Generally, the adsorption efficiency of uranium by GObased nanomaterials is poor at low solution $\mathrm{pH}$ value. As the $\mathrm{pH}$ value increases, the adsorption efficiency of uranium by GO-based nanomaterials increases, while it begins to decline when the $\mathrm{pH}$ value further increases. This trend is mainly because the solution $\mathrm{pH}$ value can affect the $\mathrm{U}(\mathrm{VI})$ species and the surface properties of GO-based nanomaterials. At low solution $\mathrm{pH}$ value, high concentration of $\mathrm{H}^{+}$competed with uranyl cations for binding sites on the surface of the adsorbent of GO-based nanomaterials, ${ }^{[114]}$ thus reducing the adsorption efficiency of uranium(VI). With the increase of solution $\mathrm{pH}$ value, the surface of the adsorbent of GO-based nanomaterials becomes negatively charged due to the deprotonation process, at the same time, positive uranyl ionic complexes such as $\mathrm{UO}_{2} \mathrm{OH}^{+}, \quad\left(\mathrm{UO}_{2}\right)_{2}(\mathrm{OH})_{2}{ }^{2+}, \quad$ and $\left(\mathrm{UO}_{2}\right)_{3}(\mathrm{OH})_{5}{ }^{+}$are formed, ${ }^{[115,116]}$ and then the electrostatic forces enhance between the positive uranyl complexes and the negatively
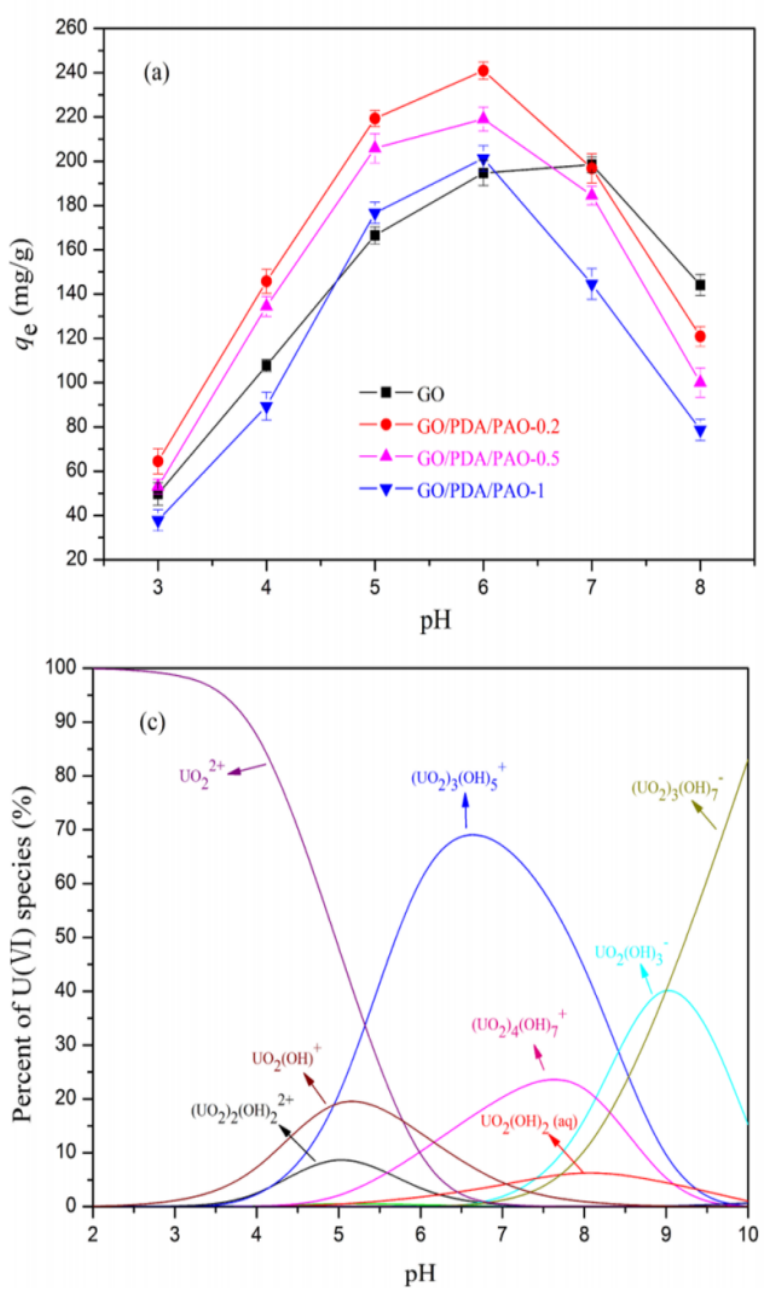

charged surface of the GO-based nanomaterials as adsorbents to improve the adsorption efficiency of uranium. Meanwhile, further increase of the solution $\mathrm{pH}$ value can induce the hydrolysis of uranium ions, which leads to the formation of anionic complexes such as $\mathrm{UO}_{2}\left(\mathrm{CO}_{3}\right)_{3}{ }^{4-}, \mathrm{UO}_{2}\left(\mathrm{CO}_{3}\right)_{2}{ }^{2-}$, $\left(\mathrm{UO}_{2}\right)_{3}(\mathrm{OH})_{7}^{-}, \mathrm{UO}_{2}(\mathrm{OH})_{3}^{-}$, or $\mathrm{UO}_{2}(\mathrm{OH})_{2}$ precipitation, and eventually to the reduction of the uranium adsorption efficiency.

\subsection{Effect of contact time and kinetic studies}

The contact time required to reach the adsorption equilibrium is an important factor to reflect the adsorption properties of adsorbents for the uranium. The change of adsorption capacity with the contact time represents the adsorption dynamics. The high specific surface area and abundant functional groups on the surface of GO-based nanomaterials play important roles to improve the adsorption rate of $\mathrm{U}(\mathrm{VI})$, and so the $\mathrm{U}(\mathrm{VI})$ adsorption of GO-based nanomaterials can reach adsorption equilibrium quickly. For example, the adsorption capacity of GO-DM-AO enhanced with the contact time, and reaches adsorption equilibrium at $30 \mathrm{~min} .{ }^{[75]} \mathrm{HO}-\mathrm{CB}[6] / \mathrm{GO}$ for $\mathrm{U}(\mathrm{VI})$
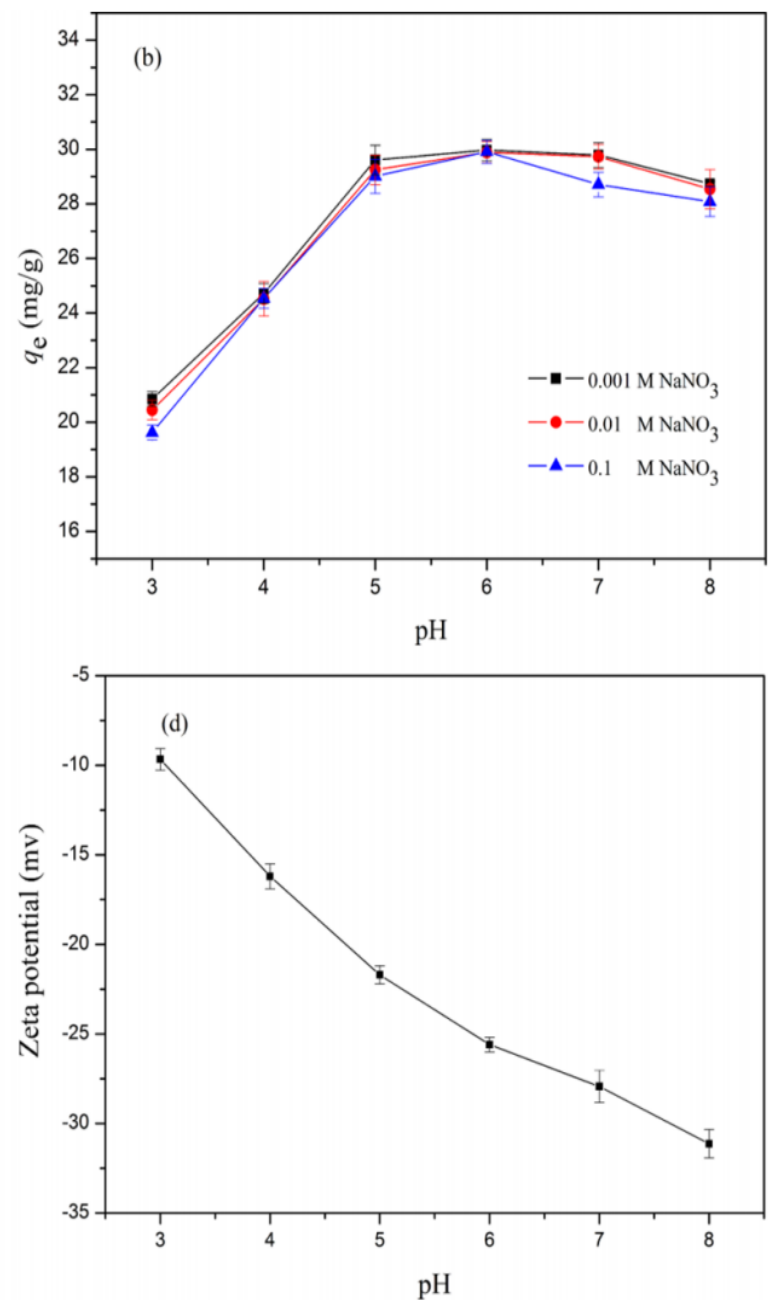

Fig. 1 (a) Effect of solution $\mathrm{pH}$ value on the removal of U(VI) by GO/PDA/PAO $\left(C_{o}=10 \mathrm{mg} / \mathrm{L}\right)$. (b) Effect of ionic strength on the removal of U(VI) by GO/PDA/PAO-0.2 $\left(C_{o}=1 \mathrm{mg} / \mathrm{L}\right)$. (c) Distribution of U(VI) species at different $\mathrm{pH}$ levels. (d) Zeta potentials of GO/PDA/PAO-0.2 ( $m=5 \mathrm{mg}, V=150 \mathrm{~mL}, t=24 \mathrm{~h}, T=298 \mathrm{~K}$ ). (Reproduced with the permission form [113], Copyright 2019 American Chemical Society) 
adsorption was very fast, and it can complete $90 \%$ of uranium adsorption within $5 \mathrm{~min}$ and reached the adsorption equilibrium within $20 \mathrm{~min} .{ }^{[93]}$ The adsorption of U(VI) onto $\mathrm{Fe}-\mathrm{Ni} / \mathrm{GO}$ was rapid because of many adsorption sites at the initial stage, and the adsorption equilibrium of U(VI) was reached after $80 \mathrm{~min} \cdot{ }^{[110]} \mathrm{Li}$ et al. found that the adsorption capacity of GO nanosheets had a sharp upsurge with the contact time until reaching an equilibrium within $60 \mathrm{~min} .^{\left[{ }^{72]}\right.}$

Generally, adsorption kinetics of GO-based nanomaterials for U(VI) consist of two stages. The initial stage is the external surface adsorption stage, in which $\mathrm{U}(\mathrm{VI})$ is absorbed rapidly to contribute significantly to the adsorption equilibrium as GO-based nanomaterials as the adsorbent has a large number of available adsorption sites. During the second stage, the adsorption process is slow and the adsorption rate is generally controlled by intra-particle diffusion until the adsorption reached equilibrium. ${ }^{[117,118]}$ In order to study the adsorption kinetics of GO-based nanomaterials for U(VI) species, pseudo-first-order kinetic and pseudo-second-order kinetic and intra-particle diffusion models are often used. For example, Zong et al. used the three models to analyze the sorption kinetic data of $\mathrm{U}(\mathrm{VI})$ ions onto CMC/MGOs. And the kinetics of sorption of $\mathrm{U}(\mathrm{VI})$ onto the $\mathrm{CMC} / \mathrm{MGOs}$ composites best fit the pseudo-second-order kinetics model
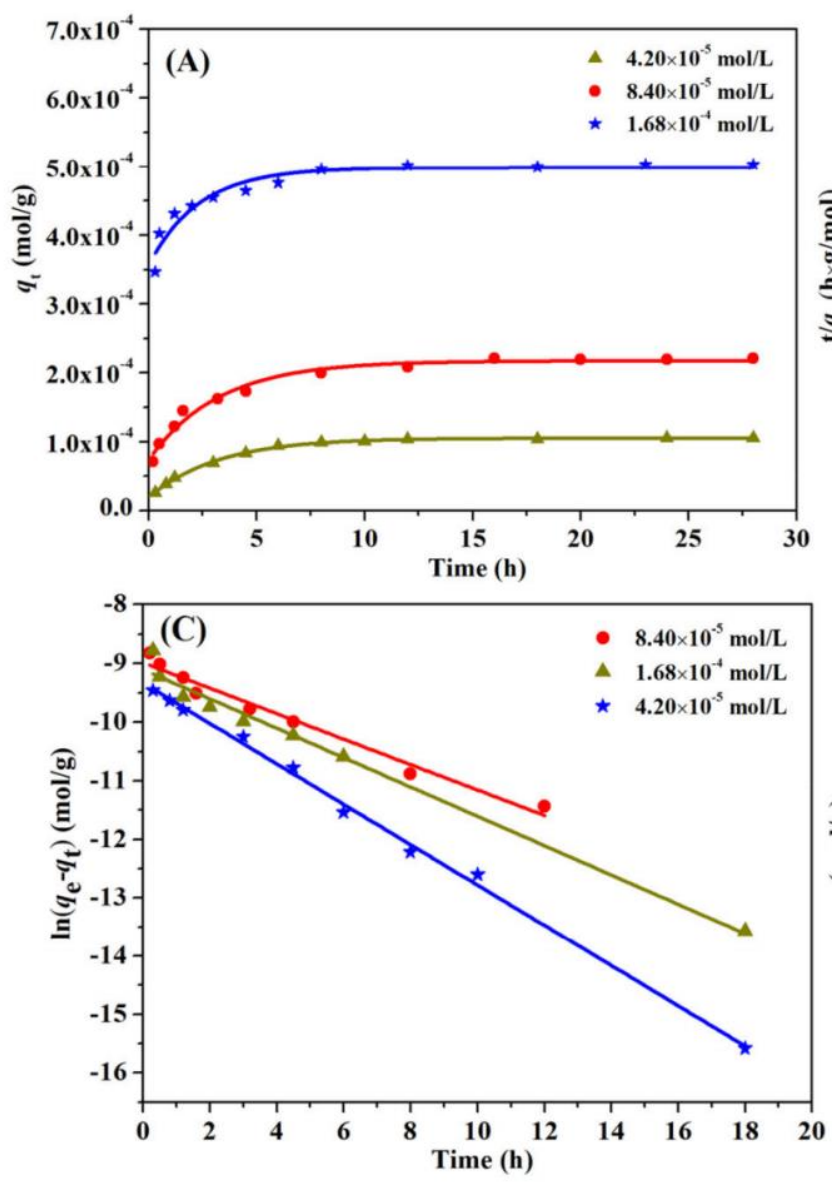

(Fig. 2). ${ }^{[71]} \mathrm{A}$ large number of literature papers reported that the adsorption of GO-based nanomaterials for U(VI) fits well to the pseudo-second-order kinetic model, which indicates that the adsorption process of GO-based nanomaterials for U(VI) is mainly controlled by chemical adsorption.

\subsection{Effect of temperature, isotherm and} thermodynamic analysis

Temperature is also one of the important environmental factors affecting the adsorption of uranium by GO-based nanomaterials. It has different effects on a series of chemicalphysical processes such as adsorption-desorption, precipitation-dissolution and oxidation-reduction of uranium. Therefore, the change of temperature can lead to the variation of adsorption capacity of GO-based nanomaterials for uranium. In order to understand the thermodynamic behaviors of uranium on GO-based nanomaterials, adsorption isotherm models have been extensively used to provide information about the amount of adsorbed uranium ions by certain GObased nanomaterials as the adsorbents and the interaction between GO-based nanomaterials as the adsorbent and the uranium species as the adsorbate. Langmuir, Freundlich, Dubinin Radushkevich, Brunauer-Emmett-Teller, and Redlich-Peterson adsorption isotherm models have been used
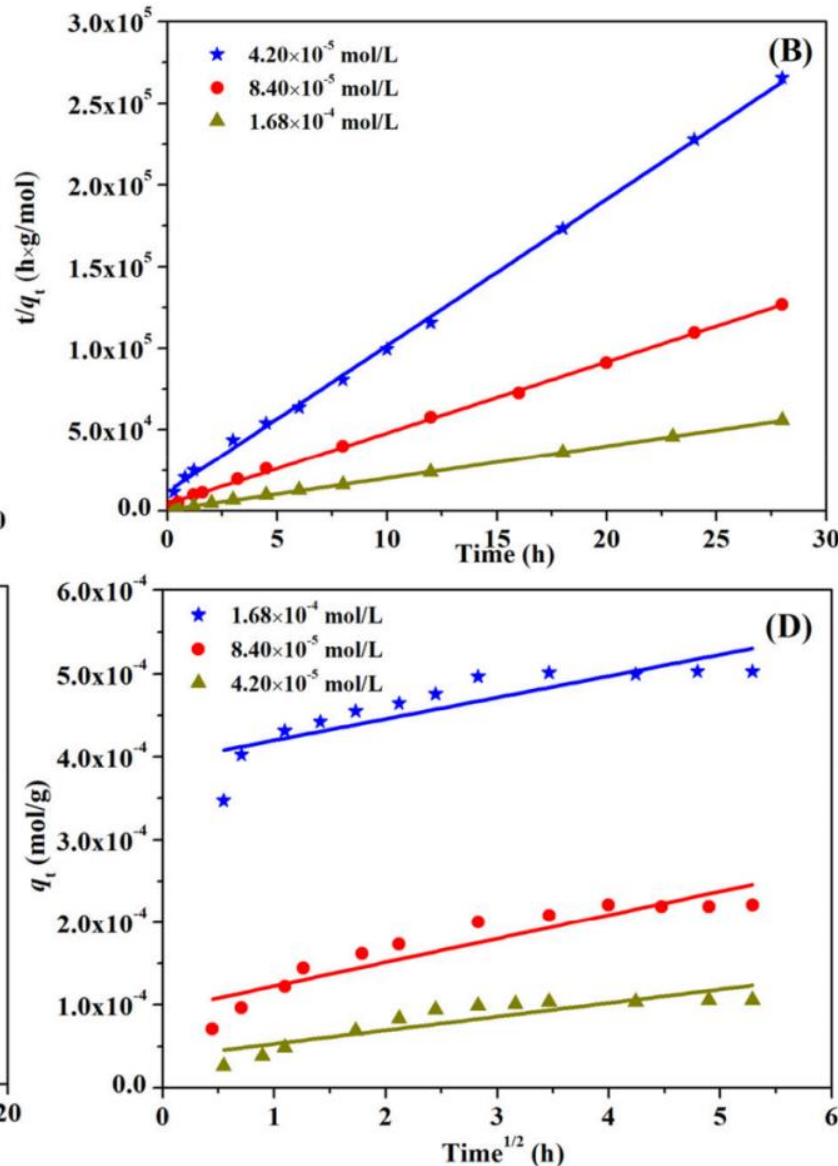

Fig. 2 (A) Influence of contact time on different initial concentration U(VI) ions adsorption onto CMC/MGOs composites. (B) Pseudo first-order model, (C) pseudo second-order model, and (D) intra-particle diffusion model fitting curve. T = $301 \mathrm{~K}, \mathrm{pH}=5.5$ $\pm 0.1, \mathrm{~m} / \mathrm{V}=0.25 \mathrm{~g} / \mathrm{L}, \mathrm{I}=0.01 \mathrm{~mol} / \mathrm{L} \mathrm{NaNO}_{3}$. (Reproduced with the permission form [71], Copyright 2016, Science China Press and Springer-Verlag Berlin Heidelberg) 
to describe the adsorption behaviors of GO-based nanomaterials for uranium. ${ }^{[19]}$ Langmuir and Freundlich models are the most common ones having been used. Langmuir isotherm assumes that all binding sites have equal affinity for an adsorbate, so a monolayer of adsorbed molecules forms with the saturation of the adsorbent. Freundlich isotherm describes adsorption onto heterogeneous surfaces that provide adsorption sites of varying affinities while the adsorbent will not be saturated. ${ }^{[120]}$ Based on the list in Table 1, it is obvious that the Langmuir isotherm model fits better for uranium adsorption by GO-based nanomaterials, indicating the adsorption procedure could be dominated by a monolayer adsorption.

Meanwhile, the values of the thermodynamic parameters, such as entropy $\left(\triangle S_{0}\right)$, enthalpy $\left(\triangle H_{0}\right)$, and Gibb's free energy $\left(\triangle G_{0}\right)$, are used to expressed the solution temperature effects. ${ }^{[121]}$ In general, the temperature has a positive effect on the adsorption capacity of uranium on GO-based nanomaterials as shown in Table 1 , in which we can see most of the adsorption process of GO-based nanomaterials for uranium was endothermic and spontaneous. Specifically, Zhang et al. found that the U(VI) adsorption on Fe-Ni/GO followed the Langmuir isotherm, and higher removal capacity of Fe-Ni/GO could be acquired at higher temperature. ${ }^{[122]}$ The adsorption of $\mathrm{U}(\mathrm{VI})$ by $\mathrm{Fe}-\mathrm{Ni} / \mathrm{GO}$ was a spontaneous endothermic process proved by the positive $\triangle H_{0}$ value and the negative $\triangle G_{0}$ value (Fig. 3). Zhao et al. reported that the adsorption capacity of $\mathrm{rGO} / \mathrm{ZIF}-67$ aerogel enhanced as the temperature increased from 293 to $313 \mathrm{~K}$, and the adsorption process was endothermic and spontaneous. ${ }^{[10]}$ Zhang et al. studied the adsorption of uranium by sulfonated GO (GOS) within the temperature range of $288.15-323.15 \mathrm{~K}^{[123]}$ Their results showed that better adsorption ability of uranium achieved at higher temperature. Similarly, Yang et al. found that the increase of temperature from $303 \mathrm{~K}$ to $333 \mathrm{~K}$ was beneficial to enhance the adsorption efficiency of GO-TW and $\mathrm{rGO} / \mathrm{Fe}_{3} \mathrm{O}_{4} / \mathrm{TW}^{[104]}$

\subsection{Effect of ionic strength and co-existing ions}

The ionic strength of the solution containing uranium affects the existing species of uranyl ions. It also affects the dual electrostatic layer thickness of GO-based nanomaterials and changes the number of binding sites of GO-based nanomaterials as the adsorbent, thus affecting their adsorption of uranium. ${ }^{[124]}$ The adsorption of different GO-based nanomaterials for uranium is affected by ion strength in different ways. The adsorption efficiency of some GO-based nanomaterials for uranium is sensitive to ionic strength change. ${ }^{[93]}$ While that of some other GO-based nanomaterials for uranium is insensitive. Bai et al. used $\mathrm{NaClO}_{4}$ as an inert electrolyte to study the effect of ionic strength on uranium sorption by $\mathrm{PAO} / \mathrm{GH} .{ }^{[14]}$ Their results showed that the ionic strength had very weak influence on the uranium adsorption by the $\mathrm{PAO} / \mathrm{GH}$, even when $\mathrm{Na}^{+}$concentration was about 265 times of uranium. Zhang et al. found that the effect of ionic strength on uranium adsorption by $\mathrm{GO}$ and sulfonated $\mathrm{GO}$ was
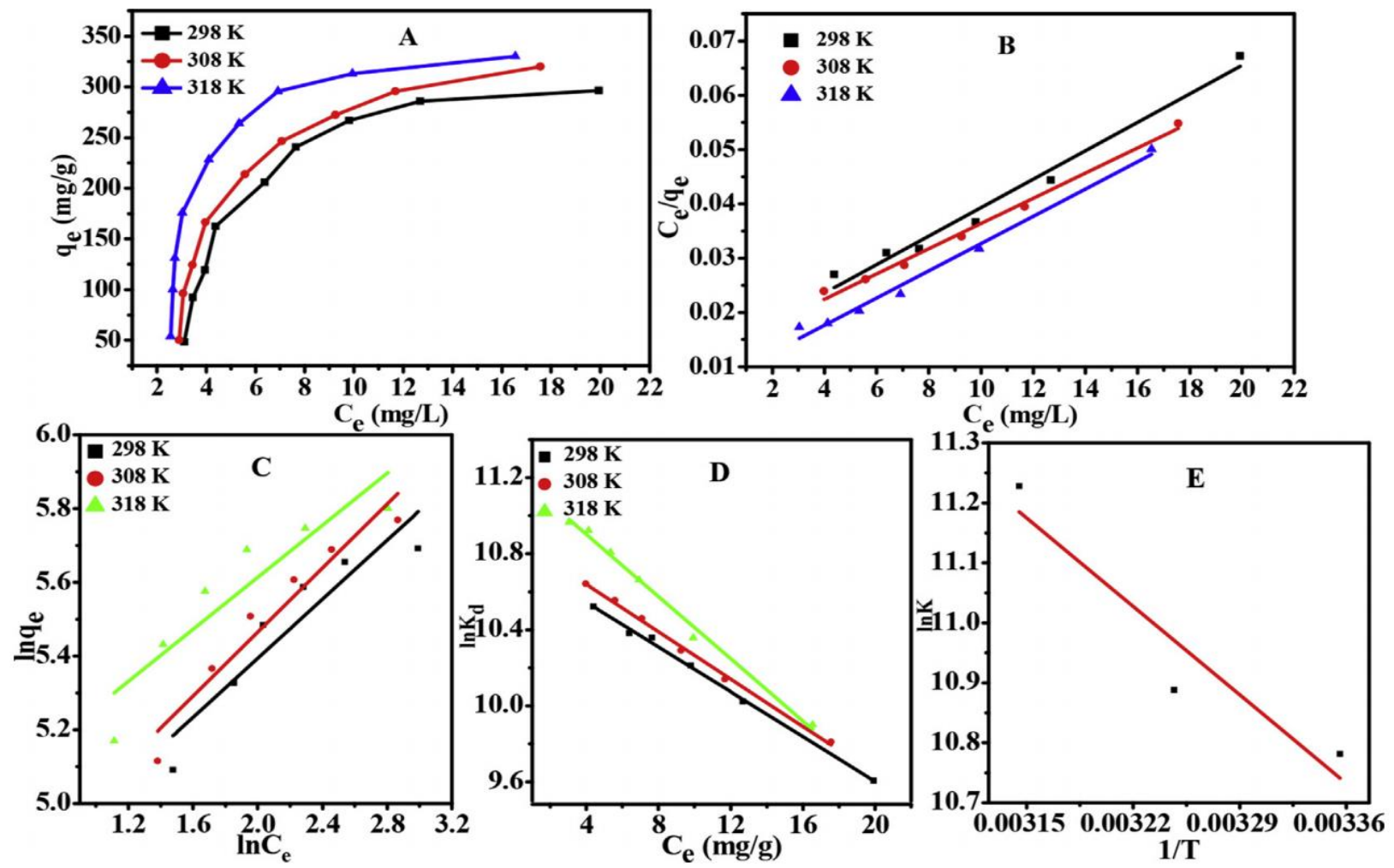

Fig. 3 Adsorption of $\mathrm{U}(\mathrm{VI})$ by $\mathrm{Fe}-\mathrm{Ni} / \mathrm{GO}$ at $\mathrm{pH}=5.5$ and $m / V=0.1 \mathrm{~g} / \mathrm{L}$ : (A) Adsorption isotherms at 298,308 and $318 \mathrm{~K}$, (B) representation of the linear Langmuir and (C) Freundlich isotherm models, (D) linear plots of $\ln K_{\mathrm{d}} \mathrm{vs} C_{e}$ for U(VI) adsorption, and (E) Van't Hoff plots for U(VI) adsorption. (Reproduced with the permission form [122], Copyright 2019 Elsevier Ltd) 
a

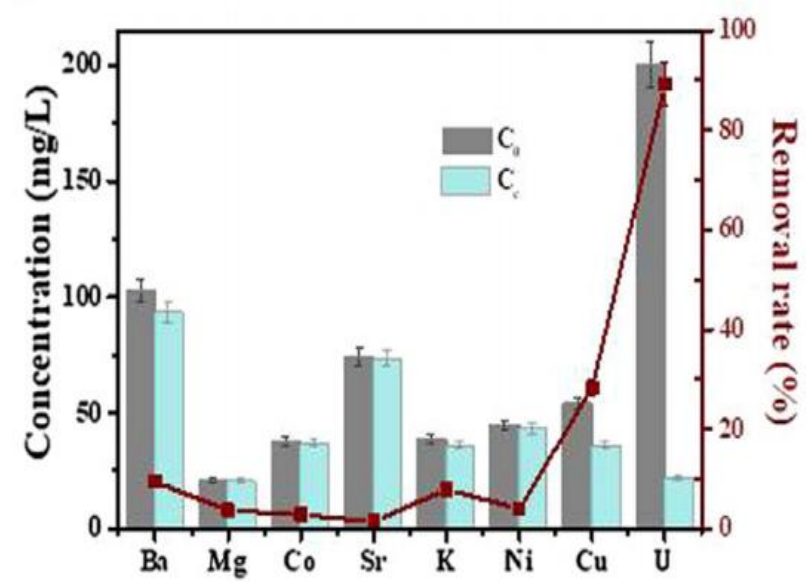

b

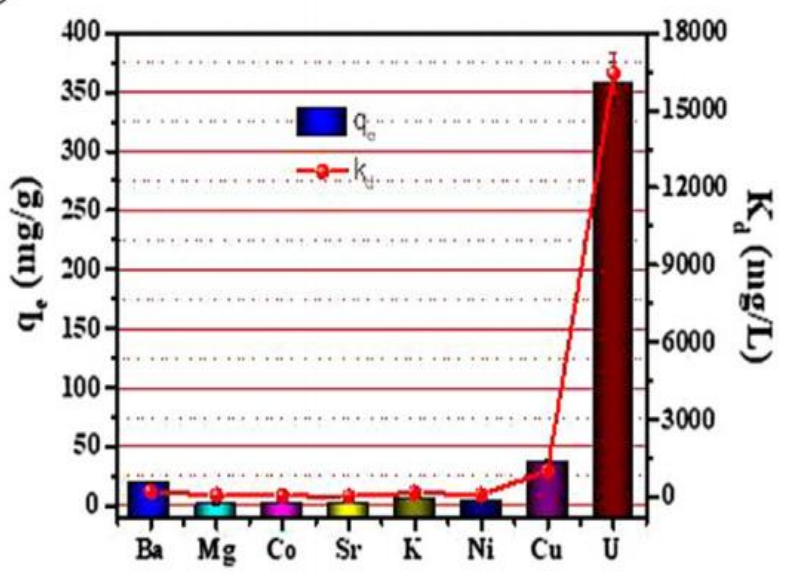

Fig. 4 Effect of co-existing ions on the removal of uranium by Ag-L-Arg-rGH in terms of (a) removal rate and (b) adsorption capacity $q_{\mathrm{e}}$ and distribution coefficient $K_{\mathrm{d} .}$ (Reproduced with the permission form [122], Copyright 2019 Elsevier Inc.)

not significant. ${ }^{[123]}$ Dai et al. found negligible influence of ionic strength on the U(VI) adsorption onto GO/PDA/PAO0.2 as shown in Fig. 1b. ${ }^{[113]}$ Zhao, et al. found that the adsorption efficiency of U(VI) by AOMGO was almost unaffected by ionic strength, which was mainly due to the formation of inner layer surface complexes between U(VI) and amidoxime and other oxygen-containing functional groups on the surface of the AOMGO rather than the formation of outer surface complexes or ion exchange. ${ }^{[00]}$

On the contrary, some other studies reached different conclusions. Wang et al. reported that the uranium adsorption capacity of GO nanoribbons (GONRs) was sensitive to the changes of ionic strength in solution. ${ }^{[125]}$ Song et al. found that the increase $\mathrm{NaClO}_{4}$ concentration could cause the uranium adsorption capacity of cyclodextrin/GO $(\mathrm{CD} / \mathrm{GO})$ to decrease, which was due to high ionic strength inhibited the transfer of $\mathrm{U}(\mathrm{VI})$ to the surface of the $\mathrm{CD} / \mathrm{GO} .^{[126]}$ In addition, high ionic strength could reduce the electrostatic repulsion between the $\mathrm{CD} / \mathrm{GO}$, which could lead to the agglomeration of the $\mathrm{CD} / \mathrm{GO}$ and then reduce the adsorption capacity of $\mathrm{U}(\mathrm{VI})$.

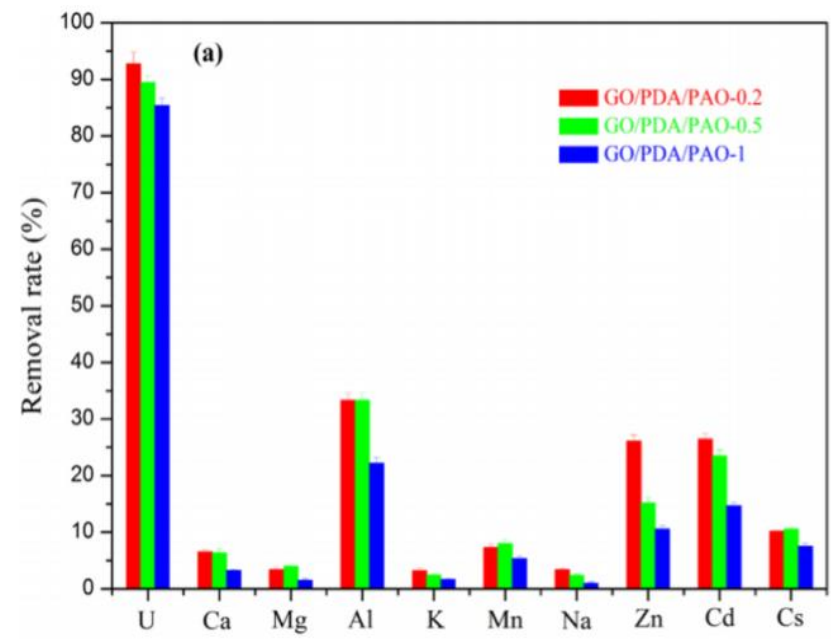

Considering the practical applications of GO-based nanomaterials for $\mathrm{U}(\mathrm{VI})$ removal, it is important to examine the competition of co-existing ions in uranium-containing aqueous solution. For example, in order to evaluate the selectivity performance of $\mathrm{Ag}$ nanoparticles and L-Arginine functionalized $\mathrm{rGO}$ composites (Ag-L-Arg-rGH) for the adsorption of $\mathrm{U}(\mathrm{VI})$, adsorption experiments were performed in the aqueous solutions with competitive ions of $\mathrm{Ba}^{2+}, \mathrm{K}^{+}$, $\mathrm{Mg}^{2+}, \mathrm{Co}^{3+}, \mathrm{Ni}^{2+}, \mathrm{Sr}^{2+}$, and $\mathrm{Cu}^{2+}$. The Ag-L-Arg-rGH showed higher removal rate (Fig. 4a), a larger adsorption capacity $q_{\mathrm{e}}$, and greater distribution coefficient $K_{\mathrm{d}}$ (Fig. 4b) for U(VI) than other ions which indicated that the Ag-L-Arg-rGH could selectively adsorb $\mathrm{U}(\mathrm{VI}) .^{[111]} \mathrm{Li}$ et al. found that common anions $\left(\mathrm{Cl}^{-}, \mathrm{NO}^{3-}, \mathrm{SO}_{4}^{2-}, \mathrm{CO}_{3}^{2-}\right.$, et al. $)$ and cations $\left(\mathrm{Cu}^{2+}, \mathrm{Ca}^{2+}\right.$, $\mathrm{Cs}^{+}, \mathrm{Mn}^{2+}, \mathrm{Sr}^{2+}$, et al.) had little effect on U(VI) removal, showing that $\mathrm{FH} / \mathrm{GOA}-800$ had good selectivity for $\mathrm{U}(\mathrm{VI}) \cdot{ }^{[45]}$ Dai et al. applied polyamidoxime/polydopamine-decorated $\mathrm{GO}(\mathrm{GO} / \mathrm{PDA} / \mathrm{PAO})$ for U(VI) adsorption from actual mine radioactive wastewater. ${ }^{[73]}$ The removal rate and $K_{\mathrm{d}}$ of the metal ions in the actual wastewater are listed in Fig. 5. The

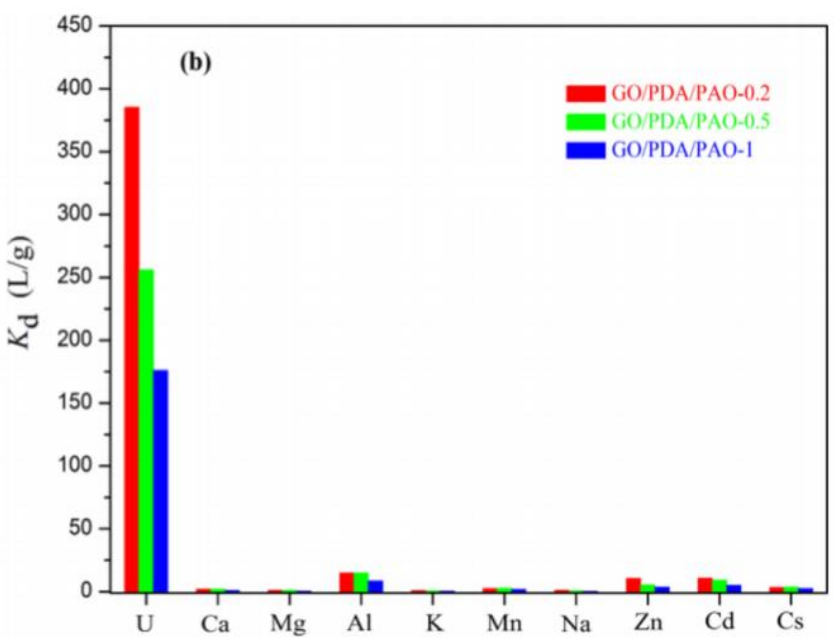

Fig. 5 (a) Removal rate and (b) $K_{d}$ of various metal ions in actual mine radioactive wastewater by polyamidoxime/polydopaminedecorated GO (GO/PDA/PAO). (Reproduced with the permission form [73], Copyright 2019 American Chemical Society.) 
Table 2. Adsorption mechanisms of GO-based nanomaterials for uranium

\begin{tabular}{|c|c|c|c|}
\hline Adsorbents & Adsorption mechanisms & Analysis techniques & Refs \\
\hline $\mathrm{APT}+\mathrm{GO}$ & $\begin{array}{l}\text { Surface complexation, ion exchange and } \\
\text { electrostatic attraction }\end{array}$ & SEM and XPS analyses & {$[132]$} \\
\hline $\mathrm{PEI} / \mathrm{GO}$ & Surface complexation & FT-IR and XPS analyses & [49] \\
\hline FH/GOA & Surface complexation and electrostatic attraction & FT-IR and XPS analyses & [45] \\
\hline MIL-68/GO & Surface complexation & XPS analyses & [87] \\
\hline Ag-L-Arg-rGH & Surface complexation & FT-IR and XPS analyses & {$[111]$} \\
\hline rGO/ZIF-67 Aerogel & surface complexation and electrostatic attraction & $\begin{array}{l}\text { Zeta potential, FT-IR and XRD } \\
\text { analyses }\end{array}$ & [10] \\
\hline $\mathrm{Fe}-\mathrm{Ni} / \mathrm{GO}$ & Reduction, surface complexation and sorption & FT-IR, EDS and XPS analyses & {$[110]$} \\
\hline GO/PDA/PAO-0.2 & Surface complexation & FT-IR and XPS analyses & [73] \\
\hline MBTA-GO & Surface complexation & $\begin{array}{l}\text { SEM, FT-IR, XPS, EXAFS analyses } \\
\text { and DFT calculations }\end{array}$ & [99] \\
\hline GZA & $\begin{array}{l}\text { Electrostatic interaction, intraparticle diffusion } \\
\text { and coordination }\end{array}$ & FT-IR and XPS analyses & [88] \\
\hline GCZ8A & $\begin{array}{l}\text { Electrostatic interaction, intraparticle diffusion } \\
\text { and coordination }\end{array}$ & FT-IR and XPS analyses & [43] \\
\hline GO-pDA-PEI & Coordination and intramolecular diffusion & XPS and FT-IR analyses & [97] \\
\hline GO/PEDOT:PSS & Surface complexation and immobilization & TEM-EDX, FT-IR and XPS analyses & {$[100]$} \\
\hline GO- DM-AO & Chelation, Coordination and ion diffusion & FT-IR and XPS analyses & [75] \\
\hline Lysinibacillus-GO & Surface complexation & XPS analyses & {$[103]$} \\
\hline $\mathrm{AO} / \mathrm{mGO}$ & Surface complexation & $\begin{array}{l}\text { EXAFS analyses and surface } \\
\text { complexation modeling }\end{array}$ & {$[133]$} \\
\hline M-GO & Reduction and surface complexation & $\begin{array}{l}\text { XPS, XANES analyses, and } \\
\text { DFT calculations }\end{array}$ & {$[134]$} \\
\hline MLGO & Surface complexation & $\begin{array}{l}\text { Batch Experiments and } \\
\text { Surface complexation modeling }\end{array}$ & {$[135]$} \\
\hline GO-CS & Inner-sphere surface complexation & $\begin{array}{l}\text { Batch Experiments and } \\
\text { FT-IR, XPS, EXAFS analyses }\end{array}$ & {$[136]$} \\
\hline
\end{tabular}

removal rate and $K_{\mathrm{d}}$ by the GO/PDA/PAO for U(VI) were higher than those for other metal ions, which indicated that the GO/PDA/PAO had selective adsorption capability for U(VI) from the actual wastewater. These results indicated that GObased nanomaterials as absorbents showed better selectivity after GO modified by other functional groups or formed composites. However, it is still a key challenge to remove and recover uranium from aqueous solution, especially in seawater. For example, vanadium has been proved to be the main competing ion for uranium recovery from seawater because of the similar size and charge of the vanadium ion with uranyl ion. Most of adsorbents showed an inferior selectivity between uranium and vanadium. ${ }^{[14,127,128]}$ Developing GO-based nanomaterials as absorbents with excellent high selectivity for uranium in harsh conditions is still needful.

In summary, the uranium adsorption efficiency and capacity of GO-based nanomaterials are greatly affected by various factors, such as the $\mathrm{pH}$ value, temperature, contact time, ionic strength, and co-existing ions of solutions. From time- and temperature-dependent adsorption experiments, kinetics, isotherm, and thermodynamic models can be established to understand the interactions between uranium and GO-based nanomaterials. Based on the above results, the kinetic models reveal that the uranium adsorption by GO- 
based nanomaterials is most fitted with pseudo-second order kinetic equations. The isotherm and thermodynamic models demonstrate that uranium adsorption by GO-based nanomaterials generally is fitted well with the Langmuir isotherm model and the adsorption process is endothermic and spontaneous.

\section{Microscopic analysis of adsorption mechanisms}

Different GO-based nanomaterials have different adsorption mechanisms with uranium. Their adsorption mechanisms usually include surface complexation or coordination,
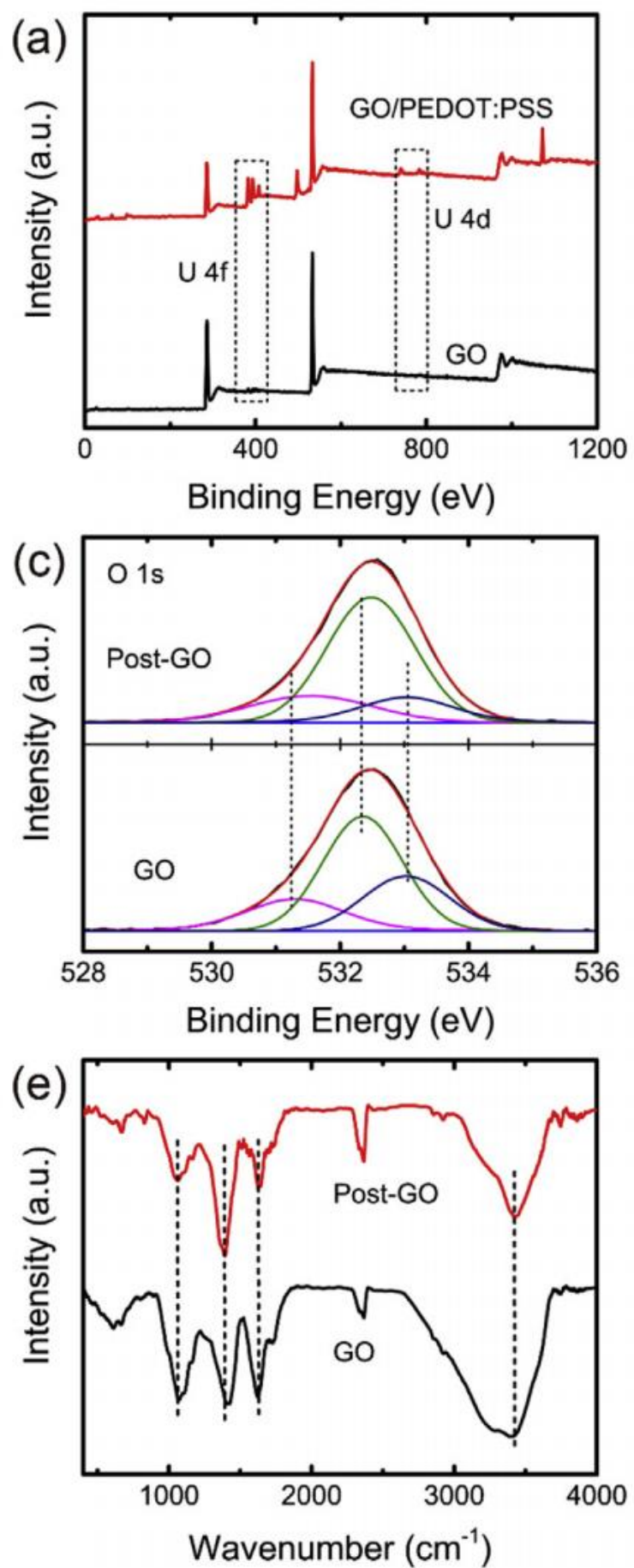

chelation, electrostatic attraction, sorption, ion exchange, ion diffusion, precipitation, reduction reaction, etc. ${ }^{[129]}$ The possible mechanisms between uranium and GO-based nanomaterials in recent studies are shown in Table 2. Generally, adsorption mechanisms are expounded from the results of batch techniques, spectroscopic analysis, surface complexation modeling, and theoretical calculations. From batch experimental results, adsorption mechanisms can be explained, such as inner-sphere surface complexation is mostly ionic strength-independent and pH-dependent while outer-sphere surface complexation or ion exchange is mostly
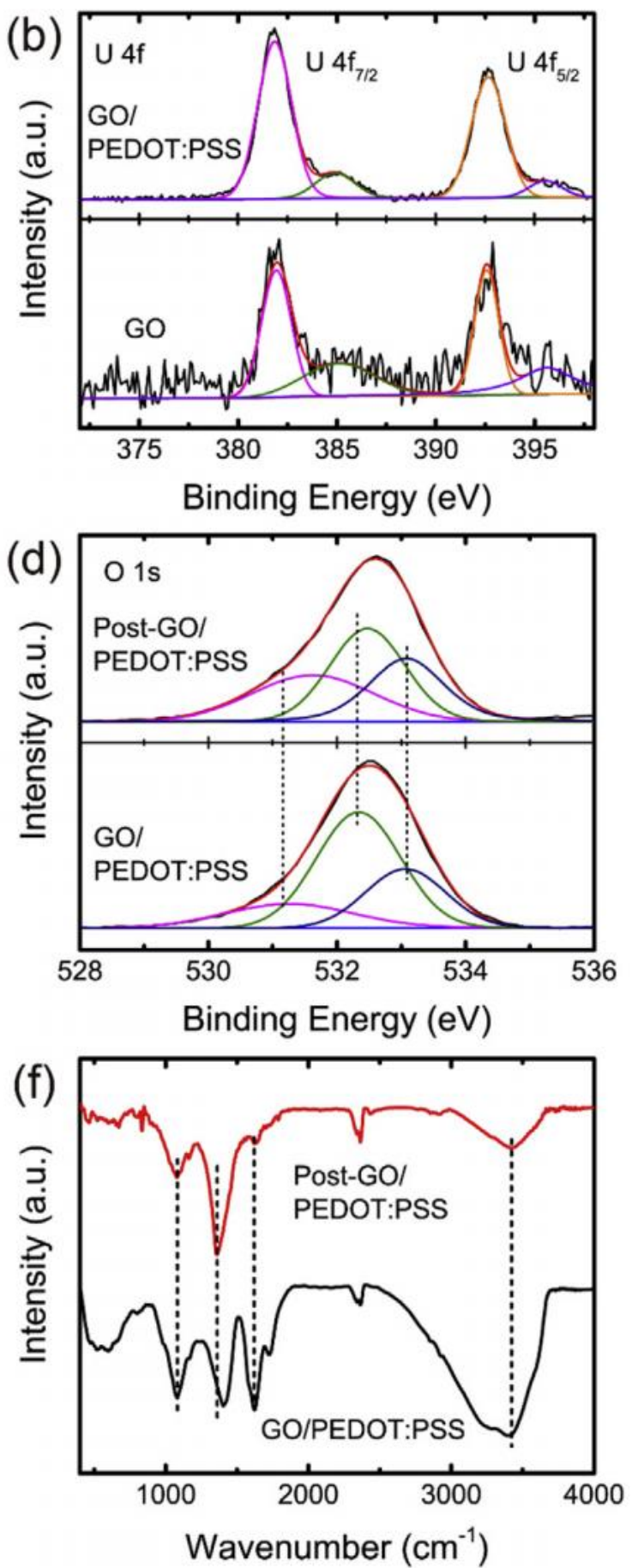

Fig. 6 Spectroscopy studies of post-GO and post-GO/PEDOT:PSS: (a) survey scans of XPS spectra and high-resolution XPS spectra of (b) U $4 \mathrm{f}$ and (c, d) O 1s, and (e, f) FT-IR spectra. (Reproduced with the permission form [100], Copyright 2019 Elsevier Ltd.) 
$\mathrm{pH}$-independent and ionic strength- dependent. ${ }^{[57,130,131]}$ We can also understand adsorption mechanisms from batch experimental adsorption data of the adsorption affecting factors that were discussed in Section 3 with the adsorption isothermal models and adsorption thermodynamics of GObased nanomaterials for uranium summarized in Table 1 . In the following sections, we will discuss the interaction mechanisms between uranium ions and GO-based nanomaterials according to spectroscopy analysis, surface complexation modeling and computational theoretical calculations.

\subsection{Spectroscopy analysis}

The adsorption mechanisms of GO-based nanomaterials for uranium can be elaborated by analyzing the species and the microstructure of uranium at molecular level and the functional groups of the GO-based nanomaterials as the adsorbent which form surface complexes with uranium. Various advanced diffraction and spectroscopic techniques have been employed, such as X-ray diffraction (XRD), X-ray photoelectric spectroscopy (XPS), Fourier transformed infrared spectroscopy (FT-IR), X-ray absorption fine structure (XAFS) spectroscopy, which includes X-ray absorption near edge structure (XANES) and extended X-ray absorption fine structure (EXAFS) spectroscopy, etc. These diffraction and spectroscopic studies are of great help to deeply understand the uranium adsorption mechanism at solid-liquid interfaces. For example, Song et al. found that the C-O/S-O bonds participated in surface complexation reaction with uranium may originate from the carboxyl/sulfonate groups instead of the alcohol hydroxyl group by FT-IR and XPS analysis (Fig. $6)^{[100]}$ The adsorption mechanism of U(VI) onto the surface of GO-DM-AO composites including chelation, coordination and ion diffusion was analyzed by FT-IR and XPS techniques (Fig. 7). ${ }^{75]}$ In Fig. 7a, the XPS spectra of adsorption U(VI) showed that uranium was attached to the GO-DM and GODM-AO. In Fig. $7 \mathrm{~b}$ and $7 \mathrm{c}$, the varied binding energies of $\mathrm{N}$ $1 \mathrm{~s}$ and $\mathrm{O} 1 \mathrm{~s}$ after adsorption of $\mathrm{U}(\mathrm{VI})$ indicated that the adsorption behavior can be attributed to N-containing and $\mathrm{O}$ containing functional groups. In Fig. 7d, the FTIR spectra of GO-DM-AO showed obvious blue shift at $3433 \mathrm{~cm}^{-1}$ and 995 $\mathrm{cm}^{-1}$, indicating the coordination or chelation between $\mathrm{U}(\mathrm{VI})$ and $-\mathrm{OH},-\mathrm{NH}_{2}, \mathrm{AO}$ groups of the GO-DM-AO ${ }^{\left[{ }^{[7]} \text { Huang }\right.}$ et al. used FT-IR, XPS and EXAFS spectroscopic methods to find the inner-sphere surface coordination structure of U(VI) with $-\mathrm{COOH},-\mathrm{OH}$, and $-\mathrm{NH}_{2}$ groups of the GO-CS samples. ${ }^{[136]}$ In addition, FT-IR spectral results showed the broadening extent increased with the increase of solution $\mathrm{pH}$, suggesting the increasing involvement of $\mathrm{CS}-\mathrm{NH}_{2}$ groups in the U(VI) coordination at high $\mathrm{pH}$. Hu et al. investigated the a

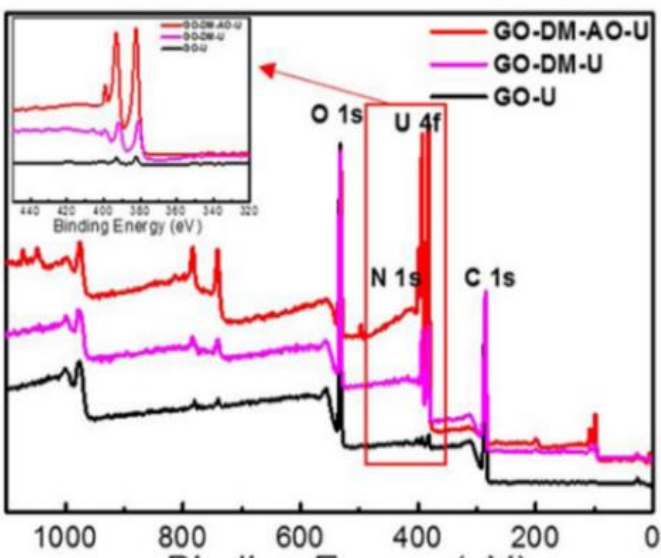

Binding Energy (eV)

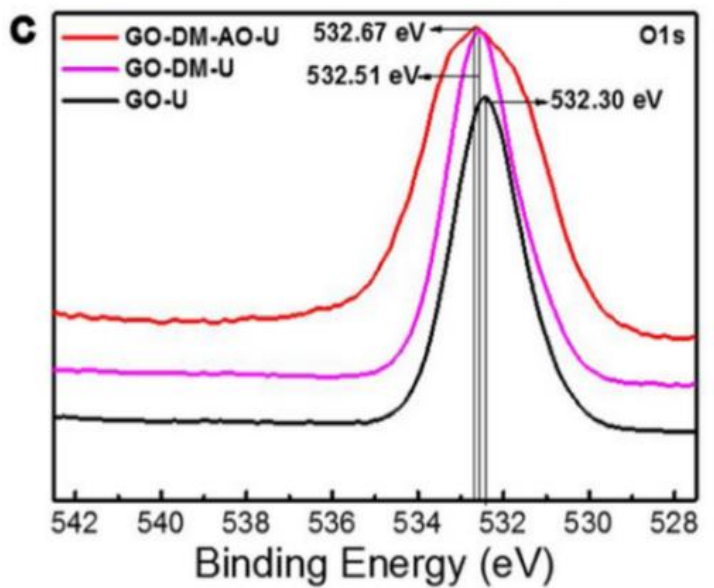

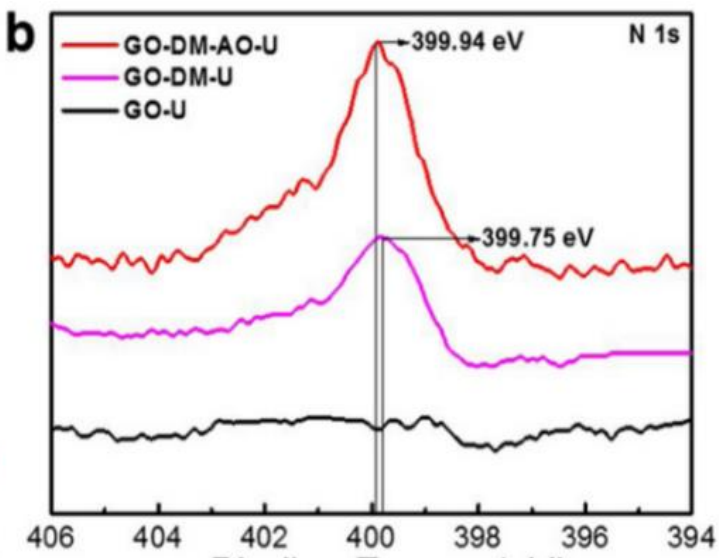

Binding Energy (eV)

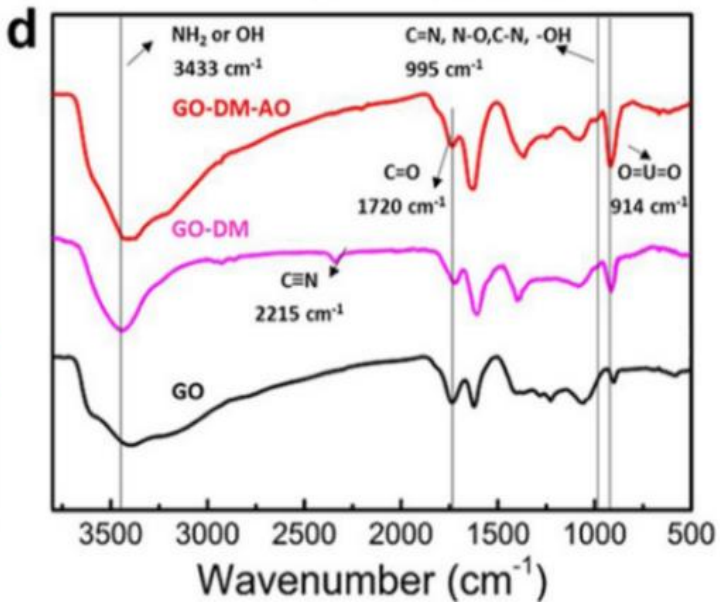

Fig. 7 Spectroscopy studies of GO-U, GO-DM-U and GO-DM-AO-U: (a) XPS survey scans, (b) N 1s and (c) O 1s XPS spectra after adsorption of U(VI), and d) FT-IR spectra. (Reproduced with the permission form [75], Copyright 2019 Elsevier B.V.) 

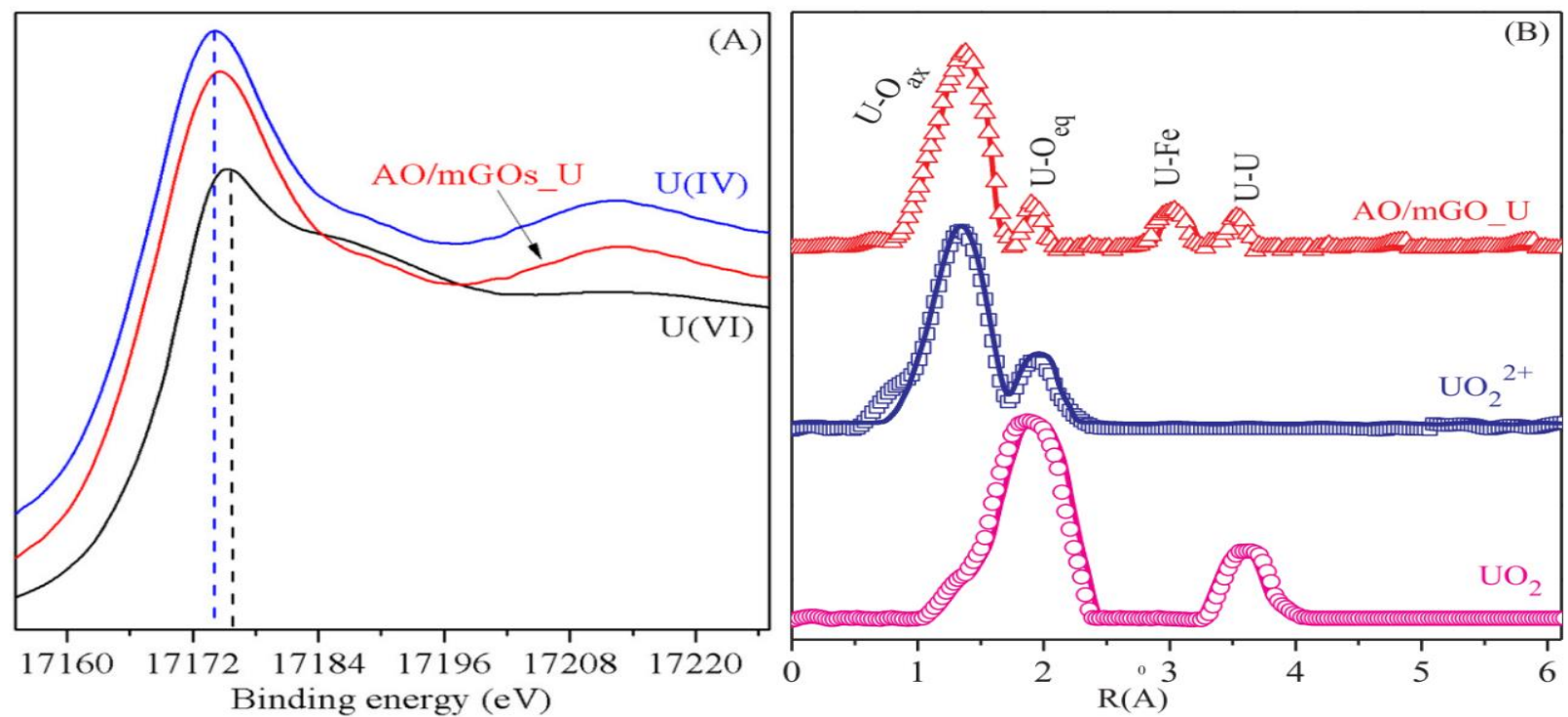

Fig. 8 Uranium LIII-edge XANES (A) and EXAFS (B) analysis of U-loaded AO/mGO under different conditions, $C_{0}=10 \mathrm{mg} / \mathrm{L}, \mathrm{m} / \mathrm{v}=0.5 \mathrm{~g} / \mathrm{L}, \mathrm{pH} 4.0, \mathrm{I}=0.01 \mathrm{~mol} / \mathrm{L}, \mathrm{T}=293 \mathrm{~K}$. (Reproduced with the permission form [140], Copyright 2014 American Chemical Society)

enrichment of amidoxime/magnetic graphene oxide $(\mathrm{AO} / \mathrm{mGO})$ for U(VI) by XANES and EXAFS analysis. ${ }^{[127]}$ The $\mathrm{k}^{2}$-weighted $\mathrm{U} L_{\text {III-edge XANES and Fourier transforms }}$ (FT) EXAFS spectra was shown in Fig. 8A and B, respectively. The adsorption energy of near-edge of $U$ loaded on the $\mathrm{AO} / \mathrm{mGO}$ were $17175.1 \mathrm{eV}$ located between that of $\mathrm{U}(\mathrm{VI})$ $(17173.8 \mathrm{eV})$ and U(IV) (17176.2 eV) (Fig. 8A), indicating that the adsorbed $\mathrm{U}(\mathrm{VI})$ was partly reduced to $\mathrm{U}(\mathrm{IV})$ by AO/mGO. In Fig. 8B, two FT features at $1.91 \AA$ and $1.40 \AA$ can be well fitted by five equatorial oxygen shell $\left(\mathrm{U}-\mathrm{O}_{\mathrm{eq}}\right.$ at $2.35 \AA$ ) and two axial oxygen shell (U-O $\mathrm{O}_{\mathrm{ax}}$ at $1.78 \AA$ ), respectively. For AO/mGO, FT feature at $3.01 \AA$ can be fitted by $0.2 \mathrm{U}-\mathrm{Fe}$ shell at $3.42 \AA$, revealing the formation of innersphere surface complexation. The other FT feature at $3.51 \AA$ was consistent with the U-U shell of UO2(s), indicating that the adsorbed $\mathrm{U}(\mathrm{VI})$ was partly reduced to U(IV) by structural $\mathrm{Fe}(\mathrm{II})$ of AO/mGO. The results of XANES and XAFS spectra demonstrated that adsorbed U(VI) was reduced to U(IV) by $\mathrm{AO} / \mathrm{mGO}$. Furthermore, the effective adsorption of U(VI) on $\mathrm{AO} / \mathrm{mGO}$ was due to the formation of inner-sphere surface complexation based on EXAFS analysis. These mentioned results indicate that spectroscopic techniques are generally helpful to understand the uranium coordinated with the functional groups on GO-based adsorbing nanomaterials.

\subsection{Surface complexation modeling}

Surface complexation models (SCMs) are effective approaches to interpret the interaction mechanisms between the solid-liquid interface of adsorbates and adsorbents. ${ }^{[137]}$ Usually, SCMs including non-electrostatic model (NEM), constant capacitance model (CCM), three-layer model (TLM) and diffuse layer model (DLM) are extensively used for the simulation of interaction mechanisms. The different surface complexes are proposed to happen depending on the various chemical factors such as ionic strength, $\mathrm{pH}$, and temperature. Results from surface complexation modeling can be compared with or verify the spectroscopic results of EXAFS, XPS, etc., which can be used to interpret their interaction mechanisms in more depth. Sun et al. used surface complexation modeling to verify their EXAFS analysis that uranium mainly formed inner surface complexes on GOs and HOOC-GO while outer surface complexes on $\mathrm{rGO}^{[138]} \mathrm{Hu}$ et al. used surface complexation modeling and found that $\mathrm{pH}$-dependence and isothermal adsorption of $\mathrm{U}(\mathrm{VI})$ on $\mathrm{AO} / \mathrm{mGO}$ can be well fitted by diffuse layer model with two inner-sphere complexes such as $\mathrm{SOUO}_{2}{ }^{+}$and $\mathrm{SOUO}_{2}\left(\mathrm{CO}_{3}\right)_{2}{ }^{3-}$ species (Fig. 9). ${ }^{[133]}$ Duster et al. tested whether three different U(VI) to MLGO ratios affected the ability of NEM and DLM and predicted U(VI) adsorption behaviors over the $\mathrm{pH}$ range of 2 to 9.5 and ionic strength from 1 to $100 \mathrm{mM} \cdot{ }^{[135]} \mathrm{NEM}$ and DLM formulations assumed interactions between discrete surfaces sites of the MLGO and the abundant aqueous U(VI) complexes over a given $\mathrm{pH}$ range. They determined that the extents of $\mathrm{U}(\mathrm{VI})$ binding required adsorption of $\mathrm{U}(\mathrm{VI})$ species, such as $\mathrm{UO}_{2}{ }^{2+}$ and uranyl hydroxides and/or carbonate, on the MLGO and calculated the stability constants for the essential U(VI)MLGO surface complexes.

\subsection{Computational theoretical calculations}

Computational chemistry calculations can be used to obtain the electronic structure, species distribution, coordination properties and thermodynamic properties of complexes formed between uranium radionuclides and GO-based nanomaterials at the molecular level, which play important roles in elucidating their solid-liquid interaction mechanisms. ${ }^{[139]}$ The comparison and mutual verification of the solid-liquid interaction data between uranium and the adsorbing GO-based nanomaterials obtained by theoretical 

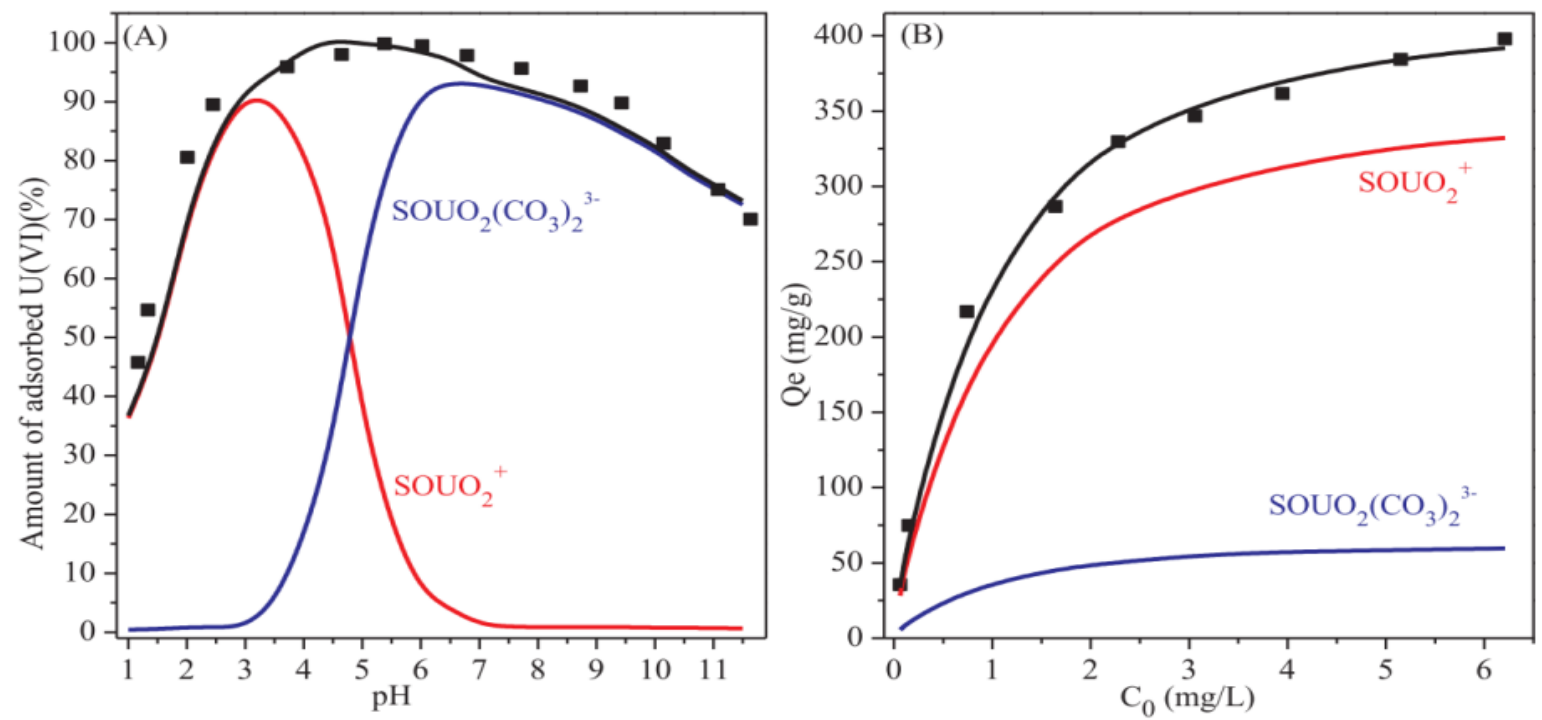

Fig. 9 Surface complexation modeling of $\mathrm{U}(\mathrm{VI})$ adsorption on $\mathrm{AO} / \mathrm{mGO}$ at (A) different $\mathrm{pH}, C_{0}=10 \mathrm{mg} / \mathrm{L}, \mathrm{m} / \mathrm{v}=0.5 \mathrm{~g} / \mathrm{L}, I=0.01$ $\mathrm{mol} / \mathrm{L}$, and $\mathrm{T}=293 \mathrm{~K}(\mathrm{~B}) \mathrm{U}(\mathrm{VI})$ concentrations with $C_{0}=10 \mathrm{mg} / \mathrm{L}, m / v=0.5 \mathrm{~g} / \mathrm{L}, \mathrm{pH}=4.0, I=0.01 \mathrm{~mol} / \mathrm{L}$, and $\mathrm{T}=293 \mathrm{~K}$. (Reproduced with the permission form [133], Copyright 2018 Elsevier B.V.)

calculations and experimental spectroscopic results can make the experimental studies on the uranium adsorption by GObased nanomaterials more convincing and reliable. In addition, some experiments are difficult to carry out because of the radioactivity and toxicity of radionuclides, while theoretical calculations can provide an effective way to supplement the relevant adsorption research.

Density functional theory (DFT) is one of the important tools for theoretical calculations, which can calculate relevant basic data of bonding structures and adsorption energies of complexes between radionuclides and adsorbing materials in an effective way and has been well applied in the field of computational chemistry. ${ }^{[140,141]}$ For example, Yu et al. studied the $\mathrm{U}(\mathrm{VI})$ adsorption mechanism of $3 \mathrm{D} \mathrm{GA} / \mathrm{TiO}_{2}$ by $\mathrm{DFT}$ calculations and obtained a $\mathrm{Ti}-\mathrm{O} 3$ bond length of $1.972 \AA$ between 3D GA and $\mathrm{TiO}_{2}$ surface (Fig. 10). ${ }^{[142]}$ Also, the adsorption energy of the $3 \mathrm{D} \mathrm{GA} / \mathrm{TiO}_{2}$ for $\mathrm{U}(\mathrm{VI})$ was calculated to be $1.60 \mathrm{eV}$, which indicated a strong chemisorption. The strong chemisorption was further confirmed by the formation of surface complexes with U-O bond lengths of $2.348 \AA$ (U-O1) and $2.638 \AA$ (U-O2). Moreover, the adsorption mechanism was illustrated by calculating differential charge density. Charge transfer was found to occur between oxygen atom of the $3 \mathrm{D} \mathrm{GA} / \mathrm{TiO}_{2}$ and
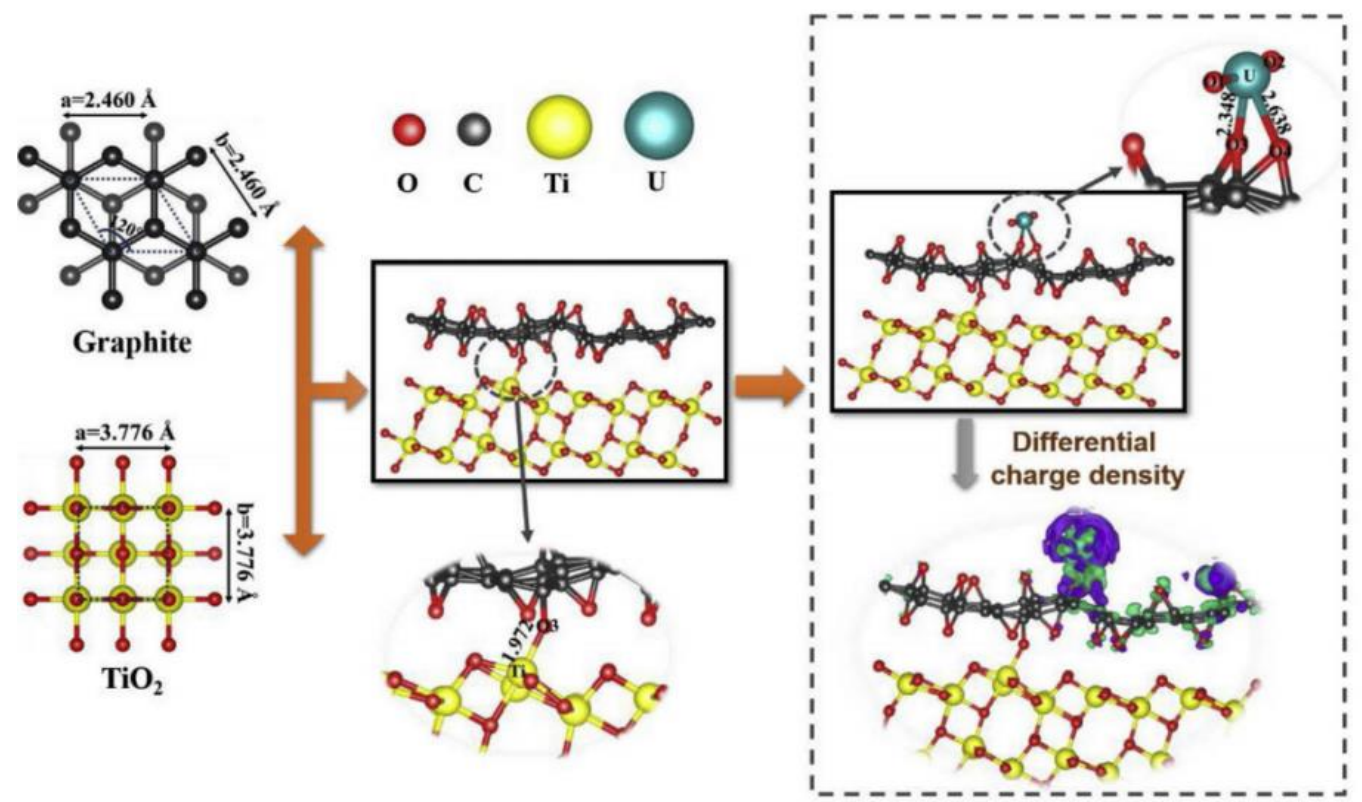

Raw materials

3D GA@ $\mathrm{TiO}_{2}$

3D GA@ $\mathrm{TiO}_{2}$ adsorbed with U(VI)

Fig. 10 Theoretical analysis on the adsorption process of U(VI) by 3D GA@ $\mathrm{TiO}_{2 .}$ (Reproduced with the permission form [142], Copyright 2019 Elsevier Ltd.) 


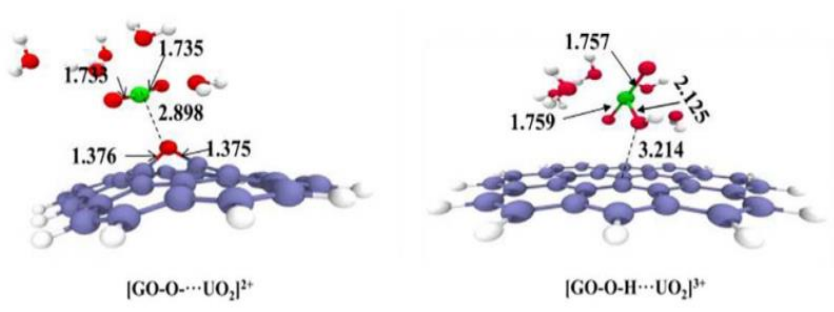

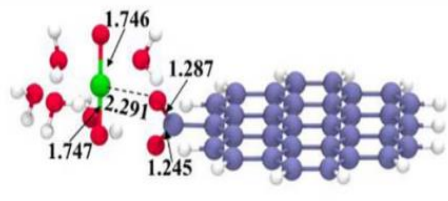

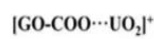

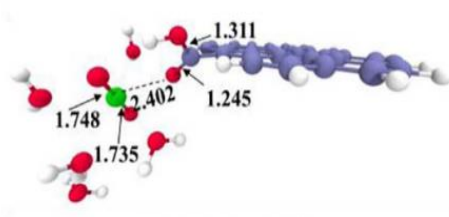

$\left[\mathrm{GO}-\mathrm{COOH} \cdots \mathrm{UO}_{2}\right]^{2}$

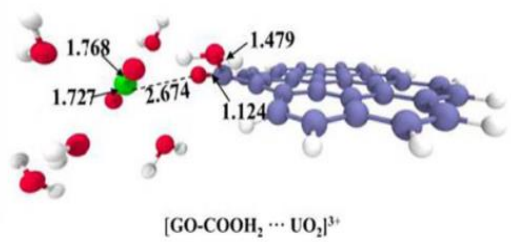

$\left[\mathrm{GO}-\mathrm{COOH}_{2} \cdots \mathrm{UO}_{2}\right]^{3+}$

Fig. 11 The optimized structures of $\mathrm{GO}(-\mathrm{O}-) /$ uranyl and $\mathrm{GO}(-\mathrm{COOH}) /$ uranyl at different pH levels. Bond lengths are in $\AA$. (Reproduced with the permission form [143], Copyright 2018 Elsevier B.V.)

the uranium atom, which proved the electrostatic attraction at different pH levels were shown in Fig. 11 and Fig. 12. between $\mathrm{U}(\mathrm{VI})$ and the $3 \mathrm{D} \mathrm{GA} / \mathrm{TiO}_{2}$. Using DFT, Ding et al. Taking carboxyl functionalized GO as an example to discuss calculated the binding energies of $\left[\mathrm{GO}-\mathrm{O} \ldots \mathrm{UO}_{2}\right]^{+}$and $[\mathrm{GO}-$ in detail, their optimized structures (Fig. 11) of [GO$\left.\mathrm{COO} \ldots \mathrm{UO}_{2}\right]^{+}$as $23.5 \mathrm{kcal} / \mathrm{mol}$ and $\left.51.1 \mathrm{kcal} / \mathrm{mol}, \mathrm{COO} \ldots \mathrm{UO}_{2}\right]^{+}, \quad\left[\mathrm{GO}-\mathrm{COOH} \ldots \mathrm{UO}_{2}\right]^{2+}$ and $\quad[\mathrm{GO}-$ respectively, which were high. It revealed that the carboxyl $\left.\mathrm{COOH}_{2} \ldots \mathrm{UO}_{2}\right]^{3+}$ were represented for high, neutral and low and hydroxyl groups were responsible for the high removal $\mathrm{pH}$ values, respectively. The change of $\mathrm{U}-\mathrm{O}_{\mathrm{ax}}$ bond in these efficiency of $\mathrm{U}(\mathrm{VI})$ by the magnetite-graphene oxide complexes followed the trend: it became longer as composites (M-GO). ${ }^{[134]}$

Ai et al. explained the interaction mechanism of uranium and $\mathrm{GO}$ with varying $\mathrm{pH}$ levels of the solution by means of high-level DFT with an implicit water model. ${ }^{[143]} \mathrm{A}$ further look at the bonding structures and adsorption energies of 12 GO/uranyl complexes showed that the major adsorption sites of GO were the functional groups such as carboxyl group, epoxy group, and hydroxyl group. Moreover, it was found that high $\mathrm{pH}$ value was more beneficial to the adsorption process of uranyl ions onto GO because of stronger electrostatic attraction between uranyl ions and negatively charged $\mathrm{O}$ atom. The optimized structures of $\mathrm{GO}(-\mathrm{O}-) /$ uranyl, $\mathrm{GO}(-$ $\mathrm{COOH}) /$ uranyl, $\mathrm{GO}(-\mathrm{OH}) /$ uranyl and $\mathrm{GO}(-\mathrm{OH}-\mathrm{OH}) /$ uranyl $1.746 / 1.747 \AA$ in $\left[\mathrm{GO}-\mathrm{COO} \ldots \mathrm{UO}_{2}\right]^{+}, 1.748 / 1.735 \AA$ in $[\mathrm{GO}-$ $\left.\mathrm{COOH} \ldots \mathrm{UO}_{2}\right]^{2+}$, and $1.768 / 1.727 \AA$ in $[\mathrm{GO}-$ $\left.\mathrm{COOH}_{2} \ldots \mathrm{UO}_{2}\right]^{3+}$ after the uranyl ions adsorption. The $\mathrm{U}-\mathrm{O}_{\mathrm{G}}$ bond length of the $\left[\mathrm{GO}-\mathrm{COO} \ldots \mathrm{UO}_{2}\right]^{+}$was $2.291 \AA$, and it lengthened to $2.402 \AA$ and $2.674 \AA$ with the increasing of acidity. The shorter $\mathrm{U}-\mathrm{O}_{\mathrm{G}}$ bond length of the $[\mathrm{GO}$

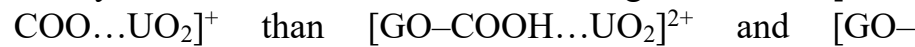
$\left.\mathrm{COOH}_{2} \ldots \mathrm{UO}_{2}\right]^{3+}$ indicated a stronger interaction between the uranyl ion and GO at high $\mathrm{pH}$ level. Moreover, the GO with bi-hydroxyl groups demonstrated the highest adsorption capacity for uranyl ions by comparing with other forms of GO. For the $\left[\mathrm{GO}-\mathrm{OH}-\mathrm{OH} \ldots \mathrm{UO}_{2}\right]^{2+}$, the uranyl ions were fastened strongly by two $\mathrm{U}-\mathrm{O}_{\mathrm{G}}$ bonds of $2.444 \AA$ and $2.463 \AA$ as shown
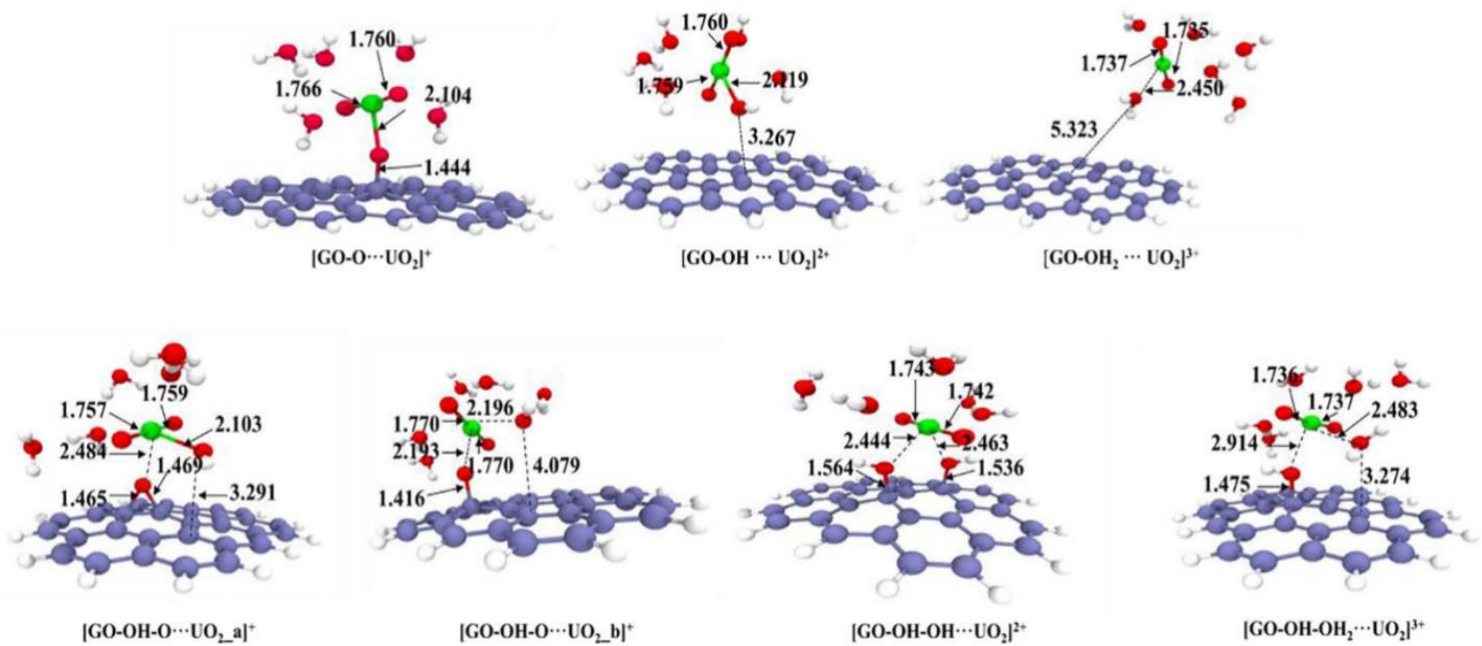

Fig. 12 The optimized structures of $\mathrm{GO}(-\mathrm{OH}) / \mathrm{uranyl}$ and $\mathrm{GO}(-\mathrm{OH}-\mathrm{OH}) / \mathrm{uranyl}$ at different pH levels. Bond lengths are in $\AA$. (Reproduced with the permission form [143], Copyright 2018 Elsevier B.V.) 
in Fig. 12. This was different from the mono-substituted case, where the uranyl ions kept away $\sim 3.267 \AA$ from the GO surface. In the meantime, the $\left[\mathrm{GO}-\mathrm{OH}-\mathrm{OH}_{2} \ldots \mathrm{UO}_{2}\right]^{3+}$ had the same uranyl ion situation that was fastened by a $\mathrm{U}-\mathrm{O}_{\mathrm{G}}$ bond of $2.914 \AA$ instead of leaving away from the GO surface. Therefore, more oxygen-containing groups might improve the adsorption performance for uranyl ions. ${ }^{[143]}$

Based on the results discussed above, GO-based nanomaterials for high uranium adsorption are mainly attributed to their surface functional groups. However, the influence degree of different functional groups of GO-based nanomaterials on uranium adsorption stays unclear due to various functional groups on GO-based nanomaterials. The binding energy attained from DFT calculations can provide some valuable information about the contribution of different groups of GO-based nanomaterials for uranium adsorption, i.e., higher binding energy means stronger interaction between uranium and functional groups of GO-based nanomaterials. ${ }^{[57]}$ For example, Sun et al. utilized DFT calculations to show evidence that the $-\mathrm{COOH}$ group formed much stronger surface complexes with U(VI) than other oxygen-containing functional groups. ${ }^{[138]}$ Their DFT calculations showed that the binding energy value of [GOs-COO $\left.\cdots \mathrm{UO}_{2}\right]{ }^{+}$was 50.5 $\mathrm{kcal} / \mathrm{mol}$, which was much higher than that of $\left[\mathrm{rGOs}^{\cdots} \mathrm{UO}_{2}\right]^{+}$ $(8.1 \mathrm{kcal} / \mathrm{mol})$. The contribution of different functional groups for binding uranium on GO-based nanomaterials can be revealed by DFT calculations at molecule level, which is difficult to be achieved from batch adsorption experiments, spectroscopy analysis and surface complexation modeling. Therefore, theoretical calculations are a good supplemental method for microscopic analysis of uranium adsorption mechanisms onto GO-based nanomaterials.

In summary, the microscopic adsorption mechanisms between uranium and GO-based nanomaterials have been clearly revealed by current studies using microscopic spectral technology, surface complexation model and theoretical calculations. It has been found that the adsorption mechanisms include surface complexation or coordination, chelation, electrostatic attraction, sorption, ion exchange, ion diffusion, precipitation, reduction reaction, etc. Other new chemical functional groups or composites introduced onto GO by surface modifications can greatly affect the interaction mechanisms. GO-based nanomaterials exhibited different interactions with uranium due to the modifications by different functional groups or composites. For example, if functional groups, such as amino and carboxyl groups are introduced onto GO, surface complexation or coordination should be the main adsorption mechanisms. If reductive substances, such as zero-valent iron or $\mathrm{Fe}-\mathrm{Ni}$ galvanic cell, are introduced onto $\mathrm{GO}$, reduction should play an important role in elimination of U(VI). Nonetheless, among these above-mentioned mechanisms, surface complexation or coordination is the most common interaction mechanisms between uranium and GObased nanomaterials because of various functional groups on $\mathrm{GO}$ or the new functional groups introduced can participate in complexing or coordinating with uranium.

\section{Conclusions and perspectives}

In summary, establishing and understanding an adequate design model for the removal of uranium species from aqueous media, isotherm, thermodynamic, and kinetics studies have been performed as essential basic prerequisites for GO-based nanomaterials as adsorbents. In common, uranium adsorption by GO-based nanomaterials mostly fits well with the Langmuir isotherm model and the adsorption process is endothermic and spontaneous. Also, kinetic modeling reveals the potential rate-controlling steps such as mass transport or chemical reaction processes. The most commonly fitted model for uranium by GO-based nanomaterials is the pseudo-second order kinetic equations. In addition, these models obtained from macroscopic batch experiments, combined with microscopic spectral technology, surface complexation model and theoretical calculations, have been applied to study the adsorption behaviors of uranium by GO-based nanomaterials, which have made the interaction mechanisms between uranium and GO-based nanomaterials more deeply and clearly revealed.

Despite great advances in GO-based nanomaterials for uranium adsorption have been attained in recent years, there are still some challenges to overcome and many issues to be solved:

(1) Hummers method is the most commonly used method for the synthesis of GO. This method faces with the problems of explosion risk, environmental pollution and long reaction cycle. Development of safe, green and rapid synthesis methods of GO is needed to reduce the preparation cost and promote the industrial applications of $\mathrm{GO}$, e.g. uranium recovery and removal discussed in this article.

(2) Improving the selectivity of GO-based nanomaterials is needed for removal and recovery of uranium because actual wastewater and seawater have high ionic strength and many co-existing ions. Especially, it is a quite great challenge to uptake uranium from seawater. Therefore, the introduction of GO-based nanomaterials with appropriate functionalities, such as amidoxime and phosphoryl groups, enables the exploration of GO-based nanomaterials for uranium with desirable selectivity, which will require further intensive research in the future.

(3) The structure of a material determines its property. ${ }^{[144]}$ Regulating the structure of GO-based nanomaterials through optimizing synthesis techniques and experimental conditions to improve their uranium adsorption performance require further studies. Moreover, the correlative relationship between molecular structure and adsorption performance should be clarified for further design of favorable GO-based nanomaterials for uranium recovery and removal.

(4) Current studies have found that most of GO-based nanomaterials with high adsorption efficiency for uranium are mainly due to their surface functional groups. However, because of the diversity of the functional groups of GO, such 
as hydroxyl, carboxyl, carbonyl, epoxy group, etc., as well as some new functional groups introduced by surface functionalized modifications, further theoretical calculations combined with experimental studies are needed to determine which functional groups on uranium adsorption plays a role or the influence degree of the different groups for uranium adsorption.

\section{Acknowledgements}

HL would like to thank financial support by the China Scholarship Council (Grant No. CSC201908430311), the Natural Science Foundation of Hunan Province (Grant No. 2018JJ3420), the Research Foundation of Education Bureau of Hunan Province (Grant No. 18A233), the Opening Project of Cooperative Innovation Center for Nuclear Fuel Cycle Technology and Equipment, University of South China. YM would like to thank the support by the IIT startup funds.

\section{Supporting Information}

Not Applicable.

\section{Conflict of Interest}

There is no conflict of interest.

\section{References}

[1] N. Middleton, The global casino: An introduction to environmental issues, Routledge, 2013.

[2] N. Panwar, S. Kaushik, S. Kothari, Renew. Sust. Energ. Rev., 2011, 15, 1513-1524, doi: 10.1016/j.rser.2010.11.037.

[3] S. Sun, C. Liao, A.M. Hafez, H. Zhu, S. Wu, Chem. Eng. J., 2018, 338, 27-45, doi: 10.1016/j.cej.2017.12.155.

[4] L. Mao, S. Mohan, Y. Mao, J. Electrochem. Soc., 2019, 166, H233, doi: 10.1149/2.1181906jes.

[5] U. Prasad, J. Prakash, S.K. Gupta, J. Zuniga, Y. Mao, B. Azeredo, A.N.M. Kannan, ACS Appl. Mater. Inter., 2019, 11, 19029-19039, doi: 10.1021/acsami.9b00150.

[6] B. D. Choudhury, B. Ibarra, F. Cesano, Y. Mao, M.N. Huda, A.R. Chowdhury, C. Olivares, M.J. Uddin, Sol. Energy, 2020, 201, 28-44, doi: 10.1016/j.solener.2020.02.035.

[7] J. Dai, S. Li, J. Bi, Z. Ma, J. Clean. Prod., 2019, 224, 198-206, doi: 10.1016/j.jclepro.2019.03.206.

[8] Z.-Q. Bai, L.-Y. Yuan, L. Zhu, Z.-R. Liu, S.-Q. Chu, L.-R. Zheng, J. Zhang, Z.-F. Chai, W.-Q. Shi, I, J. Mater. Chem. A, 2015, 3, 525-534, doi: 10.1039/C4TA04878D.

[9] L. Tan, Y. Wang, Q. Liu, J. Wang, X. Jing, L. Liu, J. Liu, D. Song, Chem. Eng. J., 2015, 259, $752-760$. 10.1016/j.cej.2014.08.015.

[10] M. Zhao, A. Tesfay Reda, D. Zhang, ACS Omega, 2020, 5, 8012-8022, doi: 10.1021/acsomega.0c00089.

[11] X. Zhang, Y. Liu, Y. Jiao, Q. Gao, P. Wang, Y. Yang, Micropor. Mesopor. Mat., 2019, 277, 52-59, doi: 10.1016/j.micromeso.2018.10.017.

[12] J. Xie, Y. Wang, W. Liu, X. Yin, L. Chen, Y. Zou, J. Diwu, Z. Chai, T.E. Angew. Chem. Int. Ed., 2017, 56, 7500-7504, doi: 10.1002/ange.201700919.
[13] I. Dincer, Renew. Sust. energ. Rev., 2000, 4, 157-175, doi: 10.1016/S1364-0321(99)00011-8.

[14] J. Bai, J. Chu, X. Yin, J. Wang, W. Tian, Q. Huang, Z. Jia, X. Wu, H. Guo, Z. Qin, Chem. Eng. J., 2019, 123553, doi: 10.1016/j.cej.2019.123553.

[15] M. Abdou, S.K. Gupta, J.P. Zuniga, Y. Mao, J. Lumin., 2019, 210, 425-434, doi: 10.1016/j.jlumin.2019.02.059

[16] M. Abdou, S.K. Gupta, J.P. Zuniga, Y. Mao, Mater. Chem. Front., 2018, 2, 2201-2211, doi: 10.1039/C8QM00266E.

[17] R. Davies, J. Kennedy, R. McIlroy, R. Spence, K. Hill, Nature, 1964, 203, 1110-1115, doi: 10.1038/2031110a0.

[18] C.J. Bopp IV, C.C. Lundstrom, T.M. Johnson, R.A. Sanford, P.E. Long, K.H. Williams, Environ. Sci. Technol., 2010, 44, 59275933, doi: 10.1021/es100643v.

[19] Y. Wang, Z. Liu, Y. Li, Z. Bai, W. Liu, Y. Wang, X. Xu, C. Xiao, D. Sheng, J. Diwu, J. Am. Chem. Soc., 2015, 137, 61446147, doi: 10.1021 /jacs.5b02480.

[20] B. Gu, W. Dong, W. Lou, N.A. Wall, Geochim. Et Cosmochim. Acta, 2010, 74, 3273-3291, doi: 10.1016/j.gca.2010.02.031.

[21] P. Bryant, J. Radiol. Prot., 2014, 34, N1, doi: 10.1088/0952$4746 / 34 / 1 / \mathrm{N} 1$

[22] K.L. Cooper, E. J. Dashner, R. Tsosie, Y.M. Cho, J. Lewis, L.G. Hudson, Toxicol. Appl. Pharm., 2016, 291, 13-20, doi: 10.1016/j.taap.2015.11.017.

[23] G. Mathews, N. Nagaiah, M. K. Kumar, M. Ambika, J. Radiol. Prot., 2015, 35, 447, doi: 10.1088/0952-4746/35/2/447.

[24] Z.-J. Li, Z.-W. Huang, W.-L. Guo, L. Wang, L.-R. Zheng, Z.F. Chai, W.-Q. Shi, Environ. Sci. Technol., 2017, 51, 5666-5674, doi: 10.1021/acs.est.6b05313.

[25] M. Xu, T. Wang, P. Gao, L. Zhao, L. Zhou, D. Hua, J. Mater. Chem. A, 2019, 7, 1214-11222, doi: 10.1039/C8TA11764K.

[26] M. Ghasemi, A.R. Keshtkar, R. Dabbagh, J. Hazard. Mater. 2011, 189, 141-149, doi: 10.1016/j.jhazmat.2011.02.011.

[27] L. Yin, B. Hu, L. Zhuang, D. Fu, J. Li, T. Hayat, A. Alsaedi, X. Wang, Chem. Eng. J., 2020, 381, 122744, doi: 10.1016/j.cej.2019.122744.

[28] S. Shi, Y. Qian, P. Mei, Y. Yuan, N. Jia, M. Dong, J. Fan, Z. Guo, N. Wang, Nano Energy, 2020, 71, 104629, doi: 10.1016/j.nanoen.2020.104629.

[29] Y.-R. He, S.-C. Li, X.-L. Li, Y. Yang, A.-M. Tang, L. Du, Z.Y. Tan, D. Zhang, H.-B. Chen, Chem. Eng. J., 2018, 338, 333340, doi: 10.1016/j.cej.2018.01.037.

[30] M. Ahmad, J. Wang, Z. Yang, Q. Zhang, B. Zhang, Chem. Eng. J., 2020, 389, 124441, doi: 10.1016/j.cej.2020.124441.

[31] Z. Dong, Z. Zhang, R. Zhou, Y. Dong, Y. Dai, X. Cao, Y. Wang, Y. Liu, Chem. Eng. J., 2020, 386, 123944, doi: 10.1016/j.cej.2019.123944.

[32] M. Szlachta, R. Neitola, S. Peräniemi, J. Vepsäläinen, Sep. Purif. Technol., 2020, 253, 117493, doi: 10.1016/j.seppur.2020.117493.

[33] A.T. Kanayev, K. Valiyev, A. Bulaev, Solid State Phenom., 2020, 299, 1104-1108, doi: 10.4028/www.scientific.net/SSP.299.1104. 
[34] F.A. Aydin, M. Soylak, Talanta, 2007, 72, 187-192, doi: 10.1016/j.talanta.2006.10.013.

[35] J.T. Amphlett, M.D. Ogden, R.I. Foster, N. Syna, K. Soldenhoff, C.A. Sharrad, Chem. Engi. J., 2018, 334, 1361-1370, doi: 10.1016/j.cej.2017.11.040.

[36] J.T. Amphlett, S. Choi, S.A. Parry, E.M. Moon, C.A. Sharrad, M.D. Ogden, Chem. Eng. J., 2019, 392, 123712, doi: 10.1016/j.cej.2019.123712.

[37] Y. Cheng, P. He, F. Dong, X. Nie, C. Ding, S. Wang, Y. Zhang, H. Liu, S. Zhou, Chem. Eng. J., 2019, 367, 198-207, doi: 10.1016/j.cej.2019.02.149.

[38] C. Liu, P.-C. Hsu, J. Xie, J. Zhao, T. Wu, H. Wang, W. Liu, J. Zhang, S. Chu, Y. Cui, Nat. Energy, 2017, 2, 1-8, doi: 10.1038/nenergy.2017.7.

[39] R. Agarwal, M. K. Sharma, Inorg. Chem., 2018, 57, $10984-$ 10992, doi: 10.1021/acs.inorgchem.8b01603.

[40] Y. Xue, M. Cao, J. Gao, Y. Gui, J. Chen, P. Liu, F. Ma, Y. Yan, M. Qiu, Sep. Purif. Technol., 2021, 255, 117753, 10.1016/j.seppur.2020.117753.

[41] Q. Sun, B. Aguila, J. Perman, A.S. Ivanov, V.S. Bryantsev, L.D. Earl, C.W. Abney, L. Wojtas, S. Ma, Nature commun., 2018, 9, 1-9, doi: 10.1038/s41467-018-04032-y.

[42] Y. Yuan, Q. Yu, J. Wen, C. Li, Z. Guo, X. Wang, N. Wang, Angew. Chem. Int. Ed., 2019, 58, 11785-11790, doi: 10.1002/anie.201906191.

[43] X. Guo, H. Yang, Q. Liu, J. Liu, R. Chen, H. Zhang, J. Yu, M. Zhang, R. Li, J. Wang, Chem. Eng. J., 2020, 382, 122850, doi: 10.1016/j.cej.2019.122850.

[44] G. Sheng, C. Huang, G. Chen, J. Sheng, X. Ren, B. Hu, J. Ma, X. Wang, Y. Huang, A. Alsaedi, Environ. Pollut., 2018, 233, 125-131, doi: 10.1016/j.envpol.2017.10.047.

[45] L. Yi, L. Li, C. Tao, D. Tao, W. Zhu, Chem. Eng. J., 2018, 347, 407-414, doi: 10.1016/j.cej.2018.04.140.

[46] A. Yang, J. Wu, C. Huang, J. Hazard. Toxic Radio, 2018, 22, 04017029, doi: 10.1061/(ASCE)HZ.2153-5515.0000381.

[47] X. Hu, Y. Wang, J.O. Yang, Y. Li, P. Wu, H. Zhang, D. Yuan, Y. Liu, Z. Wu, Z. Liu, Front. Chem. Sci. Eng., 2020, 14, 1029 1038, doi: 10.1007/s11705-019-1898-9.

[48] N.S. Alharbi, B. Hu, T. Hayat, S.O. Rabah, X. Wang, Front. Chem. Sci. Eng., 2020, 14, 1124-1135, doi: 10.1007/s11705-0201923-z.

[49] H. Liu, Y. Zhou, Y. Yang, K. Zou, R. Wu, K. Xia, S. Xie, Appl. Surf. Sci., 29019, 471, 88-95, doi: 10.1016/j.apsusc.2018.11.231.

[50] H. Liu, S. Xie, J. Liao, T. Yan, Y. Liu, X. Tang, J. Radioanal. Nucl. Ch., 2018, 317, 1349-1360, doi: 10.1007/s10967-0185992-0.

[51] D. Shi, Z. Tang, H. Huang, T. Zeng, S. Xie, Atomic Energy Sci. Technol, 2016, 50, 1556-1564, doi: 10.7538/yzk.2016.50.09.1556.

[52] J. Li, X. Wang, G. Zhao, C. Chen, Z. Chai, A. Alsaedi, T. Hayat, X. Wang, Chem. Soc. Rev., 2018, 47, 2322-2356, doi: 10.1039/C7CS00543A.

[53] L. Zhao, J. Deng, P. Sun, J. Liu, Y. Ji, N. Nakada, Z. Qiao, H. Tanaka, Y. Yang, Sci. Total Environ., 2018, 627, 1253-1263, doi: 10.1016/j.scitotenv.2018.02.006.

[54] C. Santhosh, V. Velmurugan, G. Jacob, S.K. Jeong, A.N. Grace, A. Bhatnagar, Chem. Eng. J., 2016, 306, 1116-1137, doi: 10.1016/j.cej.2016.08.053.

[55] Y. Zou, X. Wang, A. Khan, P. Wang, Y. Liu, A. Alsaedi, T. Hayat, X. Wang, Environ. Sci. Technol., 2016, 50, 7290-7304, doi: 10.1021/acs.est.6b01897.

[56] W. Yang, Q. Pan, S. Song, H. Zhang, Inorg. Chem.Front., 2019, 6, 1924-1937, doi: 10.1039/C9QI00386J.

[57] X. Wang, S. Yu, J. Jin, H. Wang, N.S. Alharbi, A. Alsaedi, T. Hayat, X. Wang, Sci. Bull., 2016, 61, 1583-1593, doi: 10.1007/s11434-016-1168-x.

[58] S.K. Hwang, S.-M. Kang, M. Rethinasabapathy, C. Roh, Y.S. Huh, Chem. Eng. J., 2020, 125428, doi: 10.1016/j.cej.2020.125428.

[59] Y. Zhang, L. Wang, N. Zhang, Z. Zhou, Rsc Adv., 2018, 8, 19895-19905, doi: 10.1039/C8RA03077D.

[60] M. Vakili, S. Deng, G. Cagnetta, W. Wang, P. Meng, D. Liu, G. Yu, Sep. Purif. Technol., 2019, 224, 373-387, doi: 10.1016/j.seppur.2019.05.040.

[61] A.K. Tolkou, I.A. Katsoyiannis, A.I. Zouboulis, Appl. Sci., 2020, 10, 3241, doi: 10.3390/app10093241.

[62] M.Y.M. Yusof, M.I. Idris, F. Mohamed, M.M. Nor, Mater. Sci. Eng., 2020, 785, 012020, doi: 10.1088/1757899X/785/1/012020.

[63] Z. Anfar, H. Ait Ahsaine, M. Zbair, A. Amedlous, A. Ait El Fakir, A. Jada, N. El Alem, Crit. Rev. Environ. Sci. Technol., 2020, 50, 1043-1084, doi: 10.1080/10643389.2019.1642835.

[64] A. Ishag, Y. Li, N. Zhang, H. Wang, H. Guo, P. Mei, Y. Sun, Environ. Res., 2020, 188, 109855, doi: 10.1016/j.envres.2020.109855.

[65] S. Chen, J. Hu, S. Han, Y. Guo, N. Belzile, T. Deng, Sep. Purif. Technol., 2020, 251, 117340, doi: 10.1016/j.seppur.2020.117340.

[66] H. Albatrni, H. Qiblawey, M.H. El-Naas, Sep. Purif. Technol. 2021, 257, 117833, doi: 10.1016/j.seppur.2020.117833.

[67] X. Liu, H. Pang, X. Liu, Q. Li, X. Wang, The Innovation, 2021, 2, 100076, doi: 10.1016/j.xinn.2021.100076.

[68] L. Wei, Y. Mao, Int. J. Hydrogen Energ., 2016, 41, $11692-$ 11699, doi: 10.1016/j.ijhydene.2016.04.030.

[69] L. Wei, K. Lozano, Y. Mao, Eng. Sci., 2018, 3, 62-66, doi: 10.30919/es8d723.

[70] Z. Wang, Y. Wang, J. Liao, Y. Yang, N. Liu, J. Tang, J. Radioanal. Nucl. Chem., 2016, 308, 1095-1102, doi: 10.1007/s10967-015-4598-z.

[71] X. Liu, X. Wang, J. Li, X. Wang, Sci. China Chem., 2016, 59, 869-877, doi: 10.1007/s11426-016-5594-Z.

[72] Z. Li, F. Chen, L. Yuan, Y. Liu, Y. Zhao, Z. Chai, W. Shi, Chem. Eng. J., 2012, 210, 539-546, doi: 10.1016/j.cej.2012.09.030.

[73] Z. Dai, Y. Sun, H. Zhang, D. Ding, L. Li, Ind. Eng. Chem. Res., 2019, 58, 19280-19291, doi: 10.1021/acs.iecr.9b03934.

[74] M. Su, Z. Liu, Y. Wu, H. Peng, D. Chen, Environ. Pollut., 2020, 268, 115786, doi: 10.1016/j.envpol.2020.115786.

[75] P. Yang, H. Zhang, Q. Liu, J. Liu, R. Chen, J. Yu, J. Hou, X. 
Bai, J. Wang, J. Hazard. Mater, 2019, 375, 320-329, doi: 10.1016/j.jhazmat.2019.05.005.

[76] C.L. Wang, Y. Li, C.L. Liu, J. Radioanal. Nucl. Ch., 2015. 304, 1017-1025, doi: 10.1007/ s10967-014-3855-x.

[77] X. Wang, Z. Chen, X. Wang, Sci. China Chem., 2015, 58, 1766-1773, doi: 10.1007/s11426-015-5435-5.

[78] T. Xinquan, Y. Xiaobo, L. Songsheng, W. Mingming, J. Radioanal. Nucl. Chem., 2015, 303, 245-253, doi: 10.1007/s10967-014-3429-y.

[79] Z.-b. Zhang, Y.-f. Qiu, Y. Dai, P.-f. Wang, B. Gao, Z.-M. Dong, X.-h. Cao, Y.-h. Liu, Z.-g. Le, J. Radioanal. Nucl. Chem., 310, 547-557, doi: 10.1007/s10967-016-4813-6.

[80] G. Zhao, T. Wen, X. Yang, S. Yang, J. Liao, J. Hu, D. Shao, X. Wang, Dalton Trans., 2012, 41, 6182-6188, doi: $10.1039 / \mathrm{c} 2 \mathrm{dt} 00054 \mathrm{~g}$.

[81] C. Ding, W. Cheng, Y. Sun, X. Wang, Dalton Trans., 2014, 43, 3888-3896, doi: 10.1039/c3dt52881b.

[82] Z., Chen, F., Yuan, L., Liu, Y., Zhao, Chai, Shi, Chem. Eng. $J .$, 2012, 210, 539-546, doi: 10.1016/j.cej.2012.09.030.

[83] Ma, Jianguo, Wu, Lipeng, Li, Song, Zhang, Hanxue, Sun, Lei, J. Radioanal. Nucl. Ch., 2016, 309, 607-614, doi: 10.1007/s10967-015-4654-8.

[84] Y. Wang, Z. Wang, Z. Gu, J. Yang, J. Liao, Y. Yang, N. Liu, J. Tang, J. Radioanal. Nucl. Ch., 2015, 304, 1329-1337, doi: 10.1007/s10967-015-3981-0.

[85] Z. Gu, Y. Wang, J. Tang, J. Yang, J. Liao, Y. Yang, N. Liu, J. Radioanal. Nucl. Chem., 2015, 303, 1835-1842, doi: 10.1007/s10967-014-3795-5.

[86] S. Chen, J. Hong, H. Yang, J. Yang, J. Environ. Radioactiv. 2013, 126, 253-258, doi: 10.1016/j.jenvrad.2013.09.002.

[87] J. Zhu, H. Zhang, Q. Liu, C. Wang, Z. Sun, R. Li, P. Liu, M. Zhang, J. Wang, Inst. Chem. E., 2019, 99, 45-52, doi: 10.1016/j.jtice.2019.01.008.

[88] X. Guo, R. Chen, Q. Liu, J. Liu, H. Zhang, J. Yu, R. Li, M. Zhang, J. Wang, ACS Sustain. Chem. Eng., 2019, 7, 6185-6195, doi: 10.1021/acssuschemeng.8b06391.

[89] P. Zong, D. Cao, Y. Cheng, S. Wang, J. Zhang, Z. Guo, T. Hayat, N.S. Alharbi, C. He, Cellulose, 2019, 26, 4039-4060. 10.1007/s10570-019-02358-4.

[90] Y. Zhao, J. Li, S. Zhang, H. Chen, D. Shao, RSC Adv., 2019, 3, 18952-18959, doi: 10.1039/C3RA42236D.

[91] D. Shao, J. Li, X. Wang, Sci. China Chem., 2014, 57, 1449 1458, doi: 10.1007/s11426-014-5195-7.

[92] S. Liu, J. Ma, W. Zhang, F. Luo, M. Luo, J. Radioanal. Nucl. Ch., 2015, 306, 507-514, doi: 10.1007/s10967-015-4162-x.

[93] S. Lang, J. Zhong, Y. Ren, T. Hao, X. Wang, J. Radioanal. Nucl. Ch., 2016, 311, 1-9, doi: 10.1007/s10967-016-5067-z.

[94] D. Shao, G. Hou, J. Li, T. Wen, X. Ren, X. Wang, Chem. Eng. J., 2014, 255, 604-612, doi: 10.1016/j.cej.2014.06.063.

[95] W. Song, X. Wang, Q. Wang, D. Shao, X. Wang, Phys. Chem. Chem. Phys., 2014, 17, 398-406, doi: 10.1039/C4CP04289A.

[96] F. Li, Z. Yang, H. Weng, G. Chen, M. Lin, C. Zhao, Chem. Eng. J., 2018, 332, 340-350, doi: 10.1016/j.cej.2017.09.038.

[97] S. Li, P. Yang, X. Liu, J. Zhang, W. Xie, C. Wang, C. Liu, Z. Guo, J. Mater. Chem. A, 2019, 7, 16902-16911, doi:
10.1039/C9TA04562G.

[98] D. Guo, X. Song, L. Zhang, W. Chen, D. Chu, L. Tan, J. Taiwan Inst. Chem. E., 2020, 106, 198-205, doi: 10.1016/j.jtice.2019.09.029.

[99] J. Ding, Z. Yan, L. Feng, F. Zhai, X. Chen, Y. Xu, S. Tang, C. Huang, L. Li, N. Pan, Environ. Pollut., 2019, 253, 221-230, doi: 10.1016/j.envpol.2019.06.109.

[100] S. Song, K. Wang, Y. Zhang, Y. Wang, C. Zhang, X. Wang, R. Zhang, J. Chen, T. Wen, X. Wang, Environ. Pollut., 2019, 250 196-205, doi: 10.1016/j.envpol.2019.04.020.

[101] S. Yang, Y. Huang, G. Huang, W. Peng, C. Guo, J. Shi, J. Radioanal. Nucl. Chem., 2020, 324, 847-855, doi: 10.1007/s10967-020-07101-z.

[102] G. Huang, W. Peng, S. Yang, J. Radioanal. Nucl. Chem., 2018, 317, 337-344, doi: 10.1007/s10967-018-5850-0.

[103] C. Zhao, J. Liu, Y. Deng, Y. Tian, G. Zhang, J. Liao, J. Yang, Y. Yang, N. Liu, Q. Sun, J. Clean. Prod., 2019, 236, 117624, doi: 10.1016/j.jclepro.2019.117624.

[104] B. Luo, L. yuan, Z. Chai, W. Shi, Q. Tan, J. Radioanal. Nucl Ch., 2016, 307, 269-276, doi: 10.1007/s10967-015-4108-3.

[105] D. Zhao, L. Chen, M. Sun, F. Li, J. Radioanal. Nucl. Chem., 2015, 306, 221-229, doi: 10.1007/s10967-015-4064-y.

[106] P. Zong, S. Wang, Y. Zhao, H. Wang, H. Pan, C. He, Chem. Eng. J., 2013, 220, 45-52, doi: 10.1016/j.cej.2013.01.038.

[107] L. Shao, X. Wang, Y. Ren, S. Wang, J. Zhong, M. Chu, H. Tang, L. Luo, D. Xie, Chem. Eng. J., 2016, 286, 311-319, doi: 10.1016/j.cej.2015.10.062.

[108] L. Tan, J. Wang, L. Qi, Y. Sun, X. Jing, L. Liu, J. Liu, D. Song, New J. Chem., 2015, 39, 868-876, doi: 10.1039/C4NJ01256A.

[109] L. Tan, Q. Liu, D. Song, X. Jing, J. Liu, R. Li, S. Hu, L. Liu, J. Wang, New J. Chem., 2015, 39, 2832-2838, doi: 10.1039/C4NJ01981D.

[110] Q. Zhang, D. Zhao, Y. Ding, Y. Chen, F. Li, A. Alsaedi, T. Hayat, C. Chen, J. Clean. Prod., 2019, 230, 1305-1315, doi: 10.1016/j.jclepro.2019.05.193.

[111] J. Zhu, H. Zhang, R. Chen, Q. Liu, J. Liu, J. Yu, R. Li, M. Zhang, J. Wang, J. Colloid. Interf. Sci., 2019, 543, 192-200, doi: 10.1016/j.jcis.2019.02.045.

[112] H. Cheng, K. Zeng, J. Yu, J. Radioanal. Nucl. Chem., 2013, 298, 599-603, doi: 10.1007/s10967-012-2406-6.

[113] Z. Dai, Y. Sun, H. Zhang, D. Ding, L. Li, Ind. Eng. Chem. Res., 2019, 58, 19280-19291, doi: 10.1021/acs.iecr.9b03934.

[114] A. Schierz, H. Zänker, Environ. Pollut., 2009, 157, 10881094, doi: 10.1016/j.envpol.2008.09.045.

[115] H. Dan, L. Chen, Q. Xian, F. Yi, Y. Ding, Sep. Purif. Technol., 2019, 210, 491-496, doi: 10.1016/j.seppur.2018.08.039. [116] X. Zhong, W. Liang, H. Wang, C. Xue, B. Hu, J. Hazard. Mater., 2021, 407, 124729, doi: 10.1016/j.jhazmat.2020.124729. [117] S. Liu, S. Li, H. Zhang, L. Wu, L. Sun, J. Ma, J. Radioanal. Nucl. Chem., 2016, 309, 607-614. 10.1007/s10967-015-4654-8.

[118] R. Han, W. Zou, Y. Wang, L. Zhu, J. Environ. Radioactiv, 2007, 93, 127-143, doi: 10.1016/j.jenvrad.2006.12.003.

[119] R. Hu, X. Wang, S. Dai, D. Shao, T. Hayat, A. Alsaedi, Chem. Eng. J., 2015, 260, 469-477, doi: 
10.1016/j.cej.2014.09.013.

[120] L. Whitty-Léveillé, C. Aumaitre, J.-F. Morin, N. Reynier, D. Larivière, Sep. Purif. Technol., 2019, 228, 115709, doi: 10.1016/j.seppur.2019.115709.

[121] C. Eiroa-Lledo, D.E. Wall, N.A. Wall, Radiochim. Acta, 2020, 108, 409-414, doi: 10.1515/ract-2019-3135.

[122] Q. Zhang, D. Zhao, Y. Ding, Y. Chen, F. Li, A. Alsaedi, T. Hayat, C. Chen, J. Clean. Prod., 2019, 230, 1305-1315, doi: 10.1016/j.jclepro.2019.05.193.

[123] Z. Zhang, Y. Qiu, Y. Dai, P. Wang, B. Gao, Z. Dong, X. Cao, Y. Liu, Z. Le, J. Radioanal. Nucl. Ch., 2016, 310, 547-557, doi: 10.1007/s10967-016-4813-6.

[124] R. Hu, D. Shao, X. Wang, Poly. Chem., 2014, 5, 6207-6215, doi: 10.1039/C4PY00743C.

[125] Y. Wang, Z. Wang, Z. Gu, J. Yang, J. Liao, Y. Yang, N. Liu, J. Tang, J Radioanal. Nucl. Ch., 2015, 304, 1329-133 , doi: 10.1007/s10967-015-3981-0.

[126] W. Song, D. Shao, S. Lu, X. Wang, Sci. China Chem., 2014, 57, 1291-1299, doi: 10.1007/s11426-014-5119-6.

[127] C.W. Abney, R.T. Mayes, T. Saito, S. Dai, Chem. Rev., 2017, 117, 13935-14013, doi: 10.1021/ acs.chemrev. 7 b00355.

[128] Y. Yuan, S. Zhao, J. Wen, D. Wang, X. Guo, L. Xu, X. Wang, N. Wang, Adv. Funct. Mater., 2019, 29, 1805380, doi: 10.1002/ adfm.201805380.

[129] Y. Wang, X. Liu, Y. Huang, T. Hayat, A. Alsaedi, J. Li, J Radioanal. Nucl. Ch., 2017, 311, 209-217, doi: 10.1007/s10967016-4924-0.

[130] Z. Li, F. Chen, L. Yuan, Y. Liu, Y. Zhao, Z. Chai, W. Shi, Chem. Eng. J., 2012, 210, 539-546, doi: 10.1016/j.cej.2012.09.030.

[131] Y. Zhao, J. Li, S. Zhang, H. Chen, D. Shao, RSC Adv., 2013, 3, 18952-18959, doi: 10.1039/C3RA42236D.

[132] X. Liu, X. Xu, J. Sun, A. Alsaedi, T. Hayat, J. Li, X. Wang, Chem. Eng. J., 2018, 343, 217-224, doi: 10.1016/j.cej.2018.02.113.

[133] B. Hu, X. Guo, C. Zheng, G. Song, D. Chen, Y. Zhu, X. Song, Y. Sun, Chem. Eng. J., 2019, 357, 66-74, doi: 10.1016/j.cej.2018.09.140.

[134] C. Ding, W. Cheng, X. Nie, F. Yi, Chem. Eng. J., 2017, 324, 113-121, doi: 10.1016/j.cej.2017.05.023.

[135] T. A. Duster, J. E. Szymanowski, J.B. Fein, Environ. Sci. Technol., 2017, 51, 8510-8518, doi: 10.1021/acs.est.6b05776.

[136] Z. Huang, Z. Li, L. Zheng, L. Zhou, Z. Chai, X. Wang, W. Shi, Chem. Eng. J., 2017, 328, 1066-1074, doi: 10.1016/j.cej.2017.07.067.

[137] C. Ding, W. Cheng, Y. Sun, X. Wang, Dalton Trans., 2014, 43, 3888-3896, doi: 10.1039/c3dt52881b.

[138] Y. Sun, S. Yang, Y. Chen, C. Ding, W. Cheng, X. Wang, Environ. Sci. Technol., 2015, 49, 4255-4262, doi: $10.1021 / \mathrm{es} 505590 \mathrm{j}$.

[139] Q.-Y. Wu, J.-H. Lan, C.-Z. Wang, Y.-L. Zhao, Z.-F. Chai, W.-Q. Shi, J. Phys. Chem. A, 2014, 118, 10273-10280. 10.1021/jp5069945.

[140] Q.-Y. Wu, C.-Z. Wang, J.-H. Lan, C.-L. Xiao, X.-K. Wang, Y.-L. Zhao, Z.-F. Chai, W.-Q. Shi, Inorg. Chem., 2014, 53, $9607-$
9614, doi: 10.1021/ic501006p.

[141] Z.-W. Huang, Z.-J. Li, Q.-Y. Wu, L.-R. Zheng, L.-M. Zhou, Z.-F. Chai, X.-L. Wang, W.-Q. Shi, Environ. Sci. Nano., 2018, 5, 2077-2087, doi: 10.1039/C8EN00677F.

[142] S. Yu, D. Wei, L. Shi, Y. Ai, P. Zhang, X. Wang, Environ. Pollut., 2019, 251, 975-983, doi: 10.1016/j.envpol.2019.04.127.

[143] Y. Ai, Y. Liu, W. Lan, J. Jin, J. Xing, Y. Zou, C. Zhao, X. Wang, Chem. Eng. J., 2018, 343, 460-466, doi: 10.1016/j.cej.2018.03.027.

[144] X. Zhong, Z. Lu, W. Liang, X. Guo, B. Hu, Environ. Sci. Nano., 2020, 7, 3303-3317, doi: 10.1039/D0EN00793E.

\section{Author information}

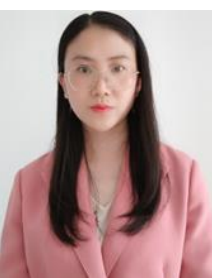

Dr. Hongjuan Liu is a lecturer at University of South China. She received her MA.Sc degree from South China University of Technology in 2009, and PhD degree from University of South China in 2018. She was a visiting scholar at Illinois Institute of Technology in 2020. She focuses on the synthesis and functionalization of nanomaterials and the exploration of their application for the treatment of radioactive pollution.

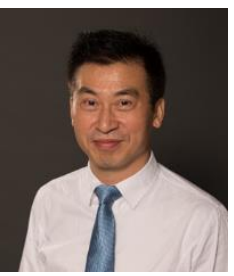

Dr. Yuanbing Mao is a professor of Chemistry at Illinois Institute of Technology. He received his B.Sc. degree from Xiangtan University, M.Sc. degree from the Institute of Chemistry, Chinese Academy of Sciences, and Ph.D. degree from the State University of New York at Stony Brook. He has earned several awards, including the Department of Defense Young Investigator Award and the Outstanding Mentorship Award from the Council on Undergraduate Research, and is a recipient of the DOE Visiting Faculty Program. As of today, he has published more than 130 peer-reviewed journal articles as well as some book chapters and patents. His research interests include nanomaterials, solid-state science and nanoscience with expertise in optoelectronics, energy storage and conversion, and environmental remediation.

Publisher's Note Engineered Science Publisher remains neutral with regard to jurisdictional claims in published maps and institutional affiliations. 